Florida International University FIU Digital Commons

\title{
The effect of music listening maps on second grade music students' preference for and understanding of orchestral music
}

Michelle Beam-Barber

Florida International University

DOI: $10.25148 /$ etd.FI14050462

Follow this and additional works at: https://digitalcommons.fiu.edu/etd

Part of the Music Education Commons

\section{Recommended Citation}

Beam-Barber, Michelle, "The effect of music listening maps on second grade music students' preference for and understanding of orchestral music" (2002). FIU Electronic Theses and Dissertations. 1472.

https://digitalcommons.fiu.edu/etd/1472 
FLORIDA INTERNATIONAL UNIVERSITY

Miami, Florida

THE EFFECT OF MUSIC LISTENING MAPS ON SECOND GRADE MUSIC STUDENTS' PREFERENCE FOR AND UNDERSTANDING OF ORCHESTRAL MUSIC

A thesis submitted in partial fulfillment of the requirements for the degree of

MASTER OF SCIENCE

in

MUSIC EDUCATION

by

Michelle Beam-Barber 
To: Dean Arthur W. Herriott

College of Arts and Sciences

This thesis, written by Michelle Beam-Barber, and entitled The Effect of Music Listening Maps on Second Grade Music Students' Preference for and Understanding of Orchestral Music, having been approved in respect to style and intellectual content is referred to you for judgment.

We have read this thesis and recommend that it be approved.

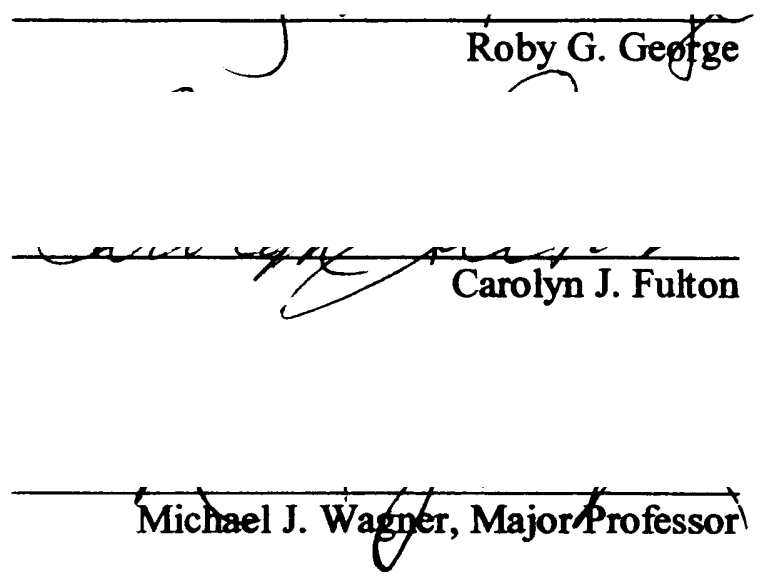

Date of Defense: March 29, 2002

The thesis of Michelle Beam-Barber is approved.

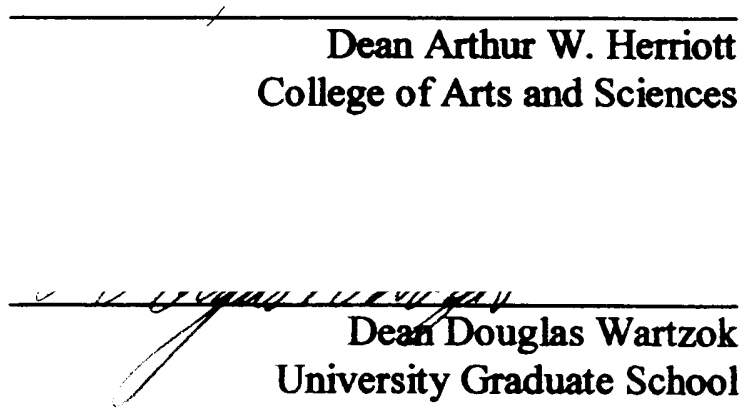

Florida International University, 2002 


\author{
ABSTRACT OF THE THESIS \\ THE EFFECT OF MUSIC LISTENING MAPS ON \\ SECOND GRADE MUSIC STUDENTS' PREFERENCE FOR \\ AND UNDERSTANDING OF ORCHESTRAL MUSIC \\ by \\ Michelle Beam-Barber \\ Florida International University, 2002 \\ Miami, Florida \\ Professor Michael J.Wagner, Major Professor
}

This study investigated the use of music listening maps to help learning and the preferences of second graders for orchestral music. Subjects were a population of four $2^{\text {nd }}$ grade classes, and were randomly divided into two groups.

The investigation was a counterbalanced, post-test only design, lasting for three consecutive classes. Two treatments/lessons were presented and a third lesson was a review. In Treatment 1 Group I used listening maps first, while Group II received instruction without listening maps. In Treatment 2, the order was reversed. Two post-tests and a comprehensive test were administered. An affective survey was administered after the treatments, measuring student preference and attitude.

When listening maps were presented, scores were significantly higher. It did not matter whether the listening maps were presented first or not. Results of the survey show student preference will increase with music listening maps. 


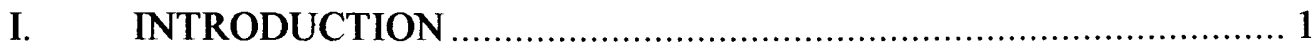

II. STATEMENT OF THE PROBLEM .................................................. 2

III. REVIEW OF RELATED LITERATURE ...................................... 3

IV. STATEMENT OF THE HYPOTHESIS ......................................... 8

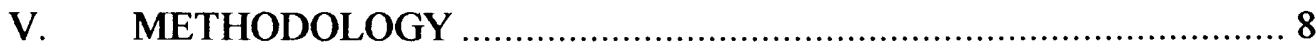

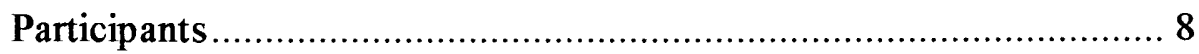

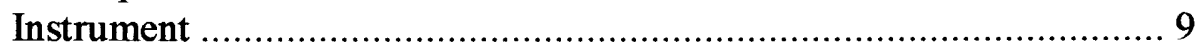

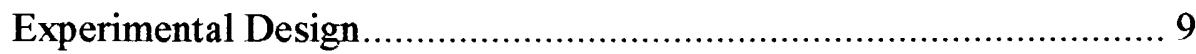

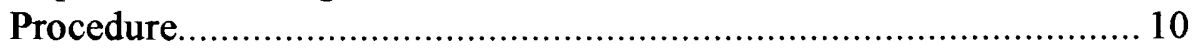

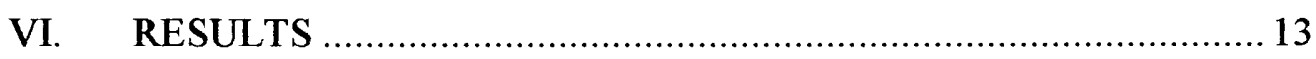

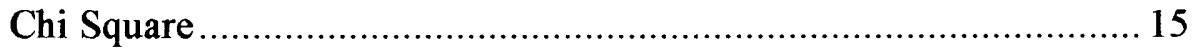

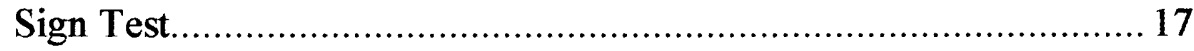

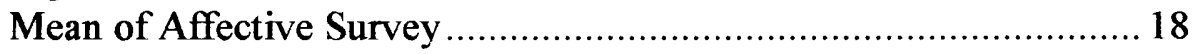

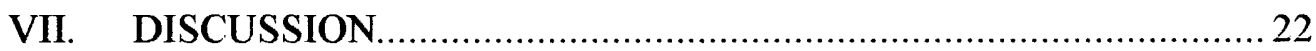

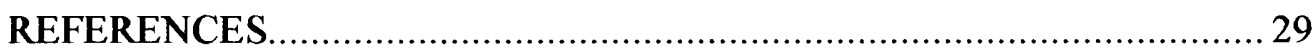

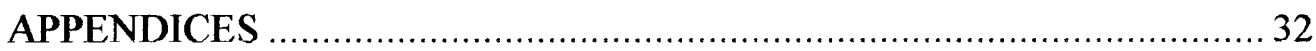




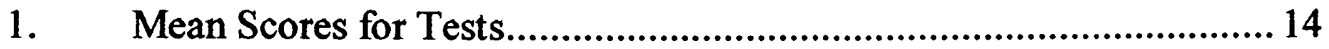

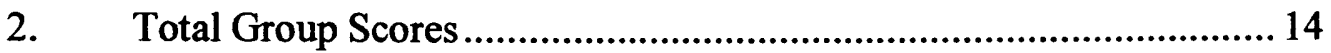

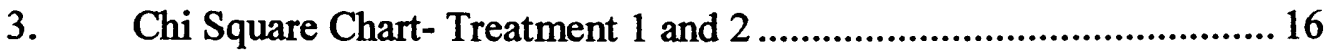

4. Chi Square- Comprehensive Test .................................................. 16

5. Chi Square Obtained Scores and Distribution of Chi Square ............. 16

6. Sign Test Comparison Chart ......................................................... 17

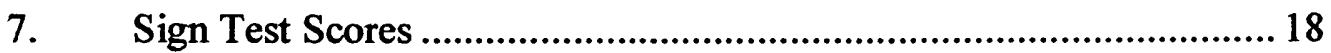

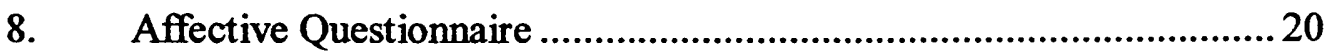


"Music educators often introduce students to 'classical' music with the hope that students will ultimately acquire an appreciation for this style that ultimately manifests itself as attending concerts and listening to this music on their own time" (Woody \& Burns, 2001, p. 57). Elementary music class is a favorable time to teach students to appreciate the various genres of music because they are receptive to new ideas. Middle school or junior high school should be avoided because, at that age, their preferences are already formed (LeBlanc, et al, 1996).

Elementary students must be actively engaged in every lesson in order to maintain interest in music. Classical 89.9, a public radio station which is a service provided by Davidson College, has created an Internet website that provides music teachers with resources for listening adventures. Music lessons provided at the site allow students to interpret music through stories, movement, drawing, and other activities.

Music listening has often been considered a passive activity and often students' listening in the classroom is ignored (Dunn, 1997; Hildebrandt, 1998; Weinberger, 1998). This is not a good practice. If students are not engaged in listening activities they will become bored and uninterested (Madsen \& Madsen, 1998).

"Listening maps" have been designed by music teachers to direct children's listening to music during class. Listening maps are defined as pictorial graphs designed to follow individual characteristics of a piece that can be followed from the beginning to the end while listening to the designated excerpt. According to Arts 
Education IDEAS, an Internet website established to provide resources for music teachers, “. . .a good map provides representation of important features. It may provide graphic icons for melody, rhythm, themes, form, dynamics, and tempo" (2001). Appendix A and B are examples of listening maps in the Share the Music series created by the MacMillian/McGraw-Hill textbook publishers to accompany Tchaikovsky's "March" from Nutcracker Suite and "The Aquarium" from Carnival of Animals (1997). By breaking complicated excerpts down into more manageable concepts students will be able to recognize and enjoy the music of the classics (Dunn, 1997). When music of the classics ". . . is presented in engaging, developmentally appropriate ways, children learn to love the classics, and begin to distinguish between many genres, periods, and styles. .." (Arts Education IDEAS, 2001). In other words, children are more likely to appreciate a piece of music if they understand the work.

If we had more data about musical thinking, both critical and creative, we could better encourage and inspire the great musicians of tomorrow, while at the same time educating the greater population about music as an art (Webster \& Richardson, 1993). Understanding listeners' musical attitudes is important in music education because teachers can then make appropriate curricular choices based on perceptions of students' needs and interests. (Brittin, 2000).

\section{Statement of the Problem}

Research shows that it is best to incorporate orchestral music written in the classic and romantic style of the $18^{\text {th }}$ and early $19^{\text {th }}$ centuries into the curriculum for 
children at a very young age (Greer, et al., 1974; LeBlanc, 1979, 1981, 1983, 1995;

Petzold, 1969; Rogers, 1957; Samaroff-Stokowski, 1996; Sims, 1990; Webster \& Richardson, 1993). Music listening preferences can be more easily taught in younger students (LeBlanc, et al, 1996). It would seem that the inclusion of more orchestral music into their curriculum would increase the likelihood of children learning to enjoy it. The present study investigates the efficiency of using music listening maps (Appendix A and B) on second grade students' learning and preference for orchestral music of the $18^{\text {th }}$ and early $19^{\text {th }}$ centuries. In this study music listening maps are defined as pictorial graphs designed to follow individual characteristics of a piece that can be followed from the beginning to the end while listening to the designated excerpt.

\section{Review of Related Literature}

Vance W. Cotter created a music listening device in 1971 that could be used to measure student preference for various types of music. The apparatus was a plexiglas box with four buttons (channels of music). It was used to evaluate the percentage of time spent listening to each channel; i.e. two types of music, white noise, and silence. Every two minutes each type of auditory stimulus moved to a different channel and could only be summoned again by pressing a different key. The key-press operated the micro switch, which resulted in the presentation of the stimulus type for the duration that the key was pressed and consequently, listening preferences were 
inferred. In that way, a record of time spent listening to any channel and tracking any preference was possible (Cotter \& Spardlin, 1971).

By actively involving students in music lessons, the educator can increase the interest and preference for classical music in young children (Sims, 1990; Johnson, 1990; Reimer, 1997; Waterfall, 1995; Weinberger, 1998). Music listening maps, in particular, are one tool, which can be used to involve students in learning and to stimulate their interest in classical music.

According to Brittin (2000), music preference is developed through such characteristics as timbre, rhythm, and tempo. Individuals may prefer one type of music to another because of the characteristics in that music. The body of music preference research shows that preference for classical art music tends to decline with increasing age during the elementary school years, while preferences for rock, country western, and other popular music grows (Geringer, 1982; Shehan-Campbell, 1983). Increasing children's preference for different styles of music is closely linked to the instructional approach used by teachers (Shehan-Campbell, 1985). Understanding the musical attitude of students is important for selecting curricular activities in the classroom based on need and interest (Brittin, 2000). With the state of technology today, MIDI and many other music programs can allow for a variety of activities to gain the interest of students for learning in the music classroom (Brittin, 2000).

It is important to provide students with the opportunity to hear in their class, music that they may not hear at home (Kaschub, 1997). In today's society it is not common to see many households with a variety of classical music readily accessible 
for children to use. Historically quoted, "A home barren of books, it is sometimes wishful thinking to expect one's children to become avid readers" (Rogers, 1957, p. 435). This philosophy can be similarly applied to music. Recordings of all types of music need to be available and used regularly for listening activities in the music classroom in order to create and develop a lasting appreciation for all kinds of music (Brittin, 2000).

According to Greer, et al (1973), the variable that is most often manipulated by music teachers is the time students are able to spend in the classroom listening to a variety of musical styles. The study also stated that factors that cannot be manipulated by the teacher are age, gender, economic and social status, and the exposure to music by the media. These researchers found that the best way to identify measured interest in different styles of music is not by verbal behavior but by the music they select to listen to in the future. Music teachers' interactions with students are important for the development of children's music selections behavior. Experimentally stated: if there is presentation, there are only three possible alternatives: (1) avoidance of future contacts with similar music, (2) increased time spent with music taught, and (3) no influence on music selection behavior (Greer, et al, 1973).

Petzold (1963) states skills in music reading are considered an essential element of musical understanding, appreciation, and performance. He found that with increasing age and musical knowledge, children were better able to perceive and appreciate auditory musical stimuli. With growing competence in aural perception, students will be able to more effectively visualize music symbols used in reading 
because they are already familiar with the "sound vocabulary" of musical symbols. Petzold suggests that school music programs should include a variety of activities designed to stimulate and challenge the children.

Many early childhood teachers feel inhibited about teaching and integrating music into the regular classroom curriculum because they do not feel qualified. However, children need an interested adult model, not necessarily an expert musician. Many children's books have music themes, which serve as resources for teachers that allow students to explore, create, and extend knowledge (McGirr, 1994). "Children are natural musicians, and exposure to music during the early years enhances the learning process by promoting language development, creativity, coordination and social interaction" (National Association for the Education of Young Children, 1997, p. 1).

The publishers of the MacMillan/McGraw-Hill Share the Music textbook series agree that the development of the ability to listen thoughtfully to music requires a systematic presentation of the music. Listening is best taught through the presentation of a short piece and gradually expanded to longer pieces as the attention span allows for it. Active involvement of the students is important in order to maintain their interest in the music (MacMillan/McGraw-Hill, 2000).

Dunn (1997) found that with college students music listening maps can change the way students listen to music. Dunn first taught his students to follow a listening map. After learning how to follow a map the students were encouraged to listen creatively to a musical selection and to create their own listening map to follow. He 
found that this creative process allows students to understand and enjoy non-rock music. In a teacher-oriented article, Listening Maps by Arts Education IDEAS, it is stated that by allowing students to reinterpret the music and make their own listening map "you have created a interactive activity that can help children make the music their own, a part of their music memory forever" (Abucewicz, 2001).

The MacMillan/McGraw-Hill Share the Music textbook series emphasizes music listening through the presentation of music listening maps. These maps are constructed in order to guide students through classical music selections with pictorial images to follow. The graphs represent characteristics of the music to be taught such as style, dynamics, form, rhythm, etc. The listening activities provided in the textbook series for teachers are lessons with guides and transparencies for accurate planning and implementation of music history activities (Macmillan/McGraw-Hill, 2000).

The organization Arts Education IDEAS provides a variety of resources and activities for music educators. Currently some of the resources are provided free to educators on the Internet URL http://www.aeideas.com/listeningmaps.html and more resources are available for purchase from the company. The listening section focuses on the integration of music listening maps into the curriculum. "The classics carry the organizational features and patterns of our culture, and systematic listening over time develops cognitive pathways that enhance learning" (Arts Education IDEAS, 2001, p. 1). Clearly, more investigations should be conducted concerning the curriculums pertaining to elementary music to enhance student learning and performance. 
It is hypothesized that when music listening maps are used in a music listening lesson second grade students' learning and preference for orchestral music of the $18^{\text {th }}$ and early $19^{\text {th }}$ centuries will increase.

\section{Methodology}

\section{Participants}

The sample for this study was four classes of $2^{\text {nd }}$ grade students at a MiamiDade County elementary school classified as Title 1 in Homestead, Florida. This school is labeled Title 1 in Miami-Dade County because a majority of students receive either free or reduced cost lunch. The ethnic breakdown of the school is: $47.7 \%$ Hispanic, 30.2\% Caucasian non-Hispanic, 19.2\% African American, 2.9\% other. There are $50.4 \%$ males and $49.6 \%$ females enrolled at the school. There are six second grade classes; one gifted ESE (Exceptional Student Education), one selfcontained LEP (Limited English Proficient), and four regular classes. In order to monitor curriculum integrity the Limited English Proficient and gifted Exceptional Student Education classes were included in the teaching aspect of the study for the total population of 184 students, but eliminated from the tabulated results. The four experimental classes were randomly divided into two groups. The classes were then labeled A, B, C, and D and randomly assigned to two groups, i.e. I \& II. Each group contained 68 students, or two of the four $2^{\text {nd }}$ grade classes. 


\section{Instrument}

All classes received a test covering: 1) $\mathrm{AB}$ form after Treatment 1,2 ) the test covering ABA form after Treatment 2,3 ) the preference survey after the second treatment, and 4) a comprehensive test/test 3 covering $\mathrm{AB}$ and $\mathrm{ABA}$ form (in class 3 ) (See Figure 1). All three tests (Appendix C, D, and E) were designed by the researcher to measure the students' ability to place objects into the categories: $\mathrm{AB}$ and ABA form after receiving both treatments and the final review in class 3 . The affective survey (Appendix F) was designed in order to measure students' attitude about the orchestral music after Treatments 1 and 2 were both completed. Test 3 was designed to measure the students' ability to place objects in $A B$ and $A B A$ form following Treatments 1 and 2.

\section{Experimental Design}

The design used in this study was a counterbalanced, post-test only design (Figure 1). Treatment 1 consisted of a music listening lesson on $A B$ form and Treatment 2 was a listening lesson about ABA form. All four groups were tested after they received the first treatment assigned to their group. The second test was administered after the students were given the second treatment. The affective survey was administered in class 2 after both treatments were given. The survey measured the preference of students for the music listening activities with and with out the use of listening maps and the preference for the music itself. The students were given a posttest during class 3 to measure their ability to remember and classify objects in $\mathrm{AB}$ and 
ABA form. Prior to test 3 a 10 -minute review was given on the information taught in the two previous classes.

Figure 1. Experimental design.

\begin{tabular}{ccccccccc}
\hline Class & $\begin{array}{c}\text { Selectio } \\
\text { n }\end{array}$ & n & Treatment 1 & Test 1 & Treatment 2 & Test 2 & Survey & Test 3 \\
\hline $\begin{array}{c}\text { A } \\
\text { (Group D }\end{array}$ & Random & 34 & Listening Maps & AB form & $\begin{array}{c}\text { No Listening } \\
\text { Maps }\end{array}$ & ABA form & Preference & $\begin{array}{c}\text { AB and } \\
\text { ABA form }\end{array}$ \\
\hline $\begin{array}{c}\text { B } \\
\text { (Group D) }\end{array}$ & Random & 34 & Listening Maps & AB form & $\begin{array}{c}\text { No Listening } \\
\text { Maps }\end{array}$ & ABA form & Preference & $\begin{array}{c}\text { AB and } \\
\text { ABA form }\end{array}$ \\
\hline $\begin{array}{c}\text { C } \\
\text { (Group I) }\end{array}$ & Random & 34 & $\begin{array}{c}\text { No Listening } \\
\text { Maps }\end{array}$ & AB form & Listening Maps & ABA form & Preference & $\begin{array}{c}\text { AB and } \\
\text { ABA form }\end{array}$ \\
\hline $\begin{array}{c}\text { D } \\
\text { Group I) }\end{array}$ & Random & 34 & $\begin{array}{c}\text { No Listening } \\
\text { Maps }\end{array}$ & AB form & Listening Maps & ABA form & Preference & $\begin{array}{c}\text { AB and } \\
\text { ABA form }\end{array}$ \\
\hline
\end{tabular}

\section{Procedure}

Prior to the beginning of the research, the four experimental classes of the six total $2^{\text {nd }}$ grades were randomly assigned to Groups I and II with 68 members each.

The study was designed to last for two consecutive 45 minute music classes and a third 20 minute period. The same music teacher taught all four groups, faithfully using the protocol for lesson plans for Treatments 1 and 2 (Appendix $G$ and H). Each experimental class (A, B, C, and D) received instruction in music listening from the teacher in two ways, with music listening maps, and without music listening maps in order to establish concurrent validity. Defined by Gay, concurrent validity is the "...degree to which the scores on a test are related to the scores on another, already established test administered at the same time, or to some other valid criterion available at the same time" $(2000$, p. 622).

Classes A and B (Group I) received Treatment 1 about $A B$ form in the same manner, i.e. using music listening maps to guide them. Classes C and D (Group II) 
received Treatment 1 without the use of listening maps. All four subgroups were given a test covering $\mathrm{AB}$ form after Treatment 1 . The following week, during their assigned music class Group I received Treatment 2, a music listening lesson on ABA form without the use of music listening maps. Group II received the same music listening lesson on ABA form, with music listening maps. Following Treatment 2 the four classes were given a test covering $\mathrm{ABA}$ form and the post preference survey was administered. The teacher conducted a 10 -minute review of the information covered in Treatments 1 and 2 (See Figure 2) and then a comprehensive test covering $\mathrm{AB}$ and $\mathrm{ABA}$ form was given to all four classes at the beginning of the third music class.

The music lessons utilized resources supplied in the MacMillan/McGraw-Hill Share the Music $2^{\text {nd }}$ grade textbook series (1997). Treatment 1, a listening lesson in $\mathrm{AB}$ form, utilized the selection "The Aquarium" from Carnival of the Animals by Saint-Saens. Treatment 2 consisted of a music listening lesson on ABA form using the "March", from The Nutcracker Suite by Tchaikovsky (MacMillan/McGraw-Hill, 1997). 
Figure 2. Procedures

\begin{tabular}{|c|c|c|c|}
\hline Groups & Class I & Class II & Class III \\
\hline \multirow{2}{*}{$\begin{array}{l}\text { A } \\
\text { and } \\
\text { B }\end{array}$} & $\begin{array}{ll}\text { Treatment } 1 \\
- & \text { History of composer } \\
- & \text { Lesson on } \mathrm{AB} \text { form } \\
\text { - } & \text { Listening lesson with } \\
& \text { listening maps } \\
\text { - } & \text { Test } 1\end{array}$ & $\begin{aligned} & \text { Treatment } 2 \\
&- \text { History of } \\
& \text { composer } \\
& \text { - } \text { Lesson on ABA } \\
& \text { Form } \\
& \text { - } \text { Listening lesson } \\
& \text { without listening } \\
& \text { maps } \\
& \text { - } \text { Test } 2 \\
& \text { - } \text { Preference Survey }\end{aligned}$ & $\begin{array}{ll}\text { Treatment } 3 \\
- & \text { Review of AB form } \\
- & \text { Review of ABA form } \\
\text { - } & \text { Test } 3\end{array}$ \\
\hline & $\begin{array}{ll}\text { Treatment } 1 \\
\text { - } & \text { History of composer } \\
\text { - } & \text { Lesson on AB form } \\
\text { - } & \text { Listening lesson with } \\
& \text { listening maps } \\
\text { - } & \text { Test } 1\end{array}$ & $\begin{aligned} & \text { Treatment } 2 \\
&- \text { History of } \\
& \text { composer } \\
& \text { - } \text { Lesson on ABA } \\
& \text { Form } \\
& \text { - } \text { Listening lesson } \\
& \text { without listening } \\
& \text { maps } \\
& \text { - } \text { Test } 2 \\
& \text { - } \text { Preference Survey }\end{aligned}$ & $\begin{aligned} \text { Treatment } 3 \\
-\quad \text { Review of AB form } \\
-\quad \text { Review of ABA form } \\
-\quad \text { Test } 3\end{aligned}$ \\
\hline \multirow{2}{*}{$\begin{array}{l}\text { C } \\
\text { and } \\
D\end{array}$} & $\begin{array}{ll}\text { Treatment } 1 \\
- & \text { History of composer } \\
\text { - } & \text { Lesson on } \mathrm{AB} \text { form } \\
\text { - } & \text { Listening lesson } \\
& \text { without listening } \\
& \text { maps } \\
\text { - } & \text { Test } 1\end{array}$ & \begin{tabular}{ll}
\multicolumn{2}{l}{ Treatment 2} \\
- & History of \\
composer \\
- $\quad$ Lesson on ABA \\
form \\
- Listening lesson \\
with listening maps \\
- Test 2 \\
- $\quad$ Preference Survey
\end{tabular} & $\begin{aligned} & \text { Treatment } 3 \\
&- \text { Review of AB form } \\
&- \text { Review of ABA form } \\
& \text { - } \text { Test } 3\end{aligned}$ \\
\hline & $\begin{array}{ll}\text { Treatment } 1 \\
- & \text { History of composer } \\
\text { - } & \text { Lesson on } \mathrm{AB} \text { form } \\
\text { - } & \text { Listening lesson } \\
& \text { without listening } \\
& \text { maps } \\
\text { - } & \text { Test } 1\end{array}$ & $\begin{array}{ll}\text { Treatment } 2 \\
- & \text { History of } \\
\text { composer } \\
\text { - } \quad \text { Lesson on ABA } \\
\text { form } \\
\text { - } \text { Listening lesson } \\
\text { with listening maps } \\
\text { - } \quad \text { Test } 2 \\
\text { - } \\
\text { Preference Survey }\end{array}$ & \begin{tabular}{ll}
\multicolumn{2}{l}{ Treatment 3} \\
- & Review of AB form \\
- & Review of ABA form \\
- & Test 3
\end{tabular} \\
\hline
\end{tabular}

Treatment $1=$ Saint-Saens

Treatment $2=$ Tchaikovsky 
Results

Prior to the study, four $2^{\text {nd }}$ grade classes were randomly placed into two groups with approximately 68 subjects in each group. Group I contained classes A and B and Group II contained classes C and D. Upon completing the treatments, thirteen of the original 136 students were eliminated from the study because they were absent from school during one or both of the treatments. This was done in order to ensure that the results at the end of the study could be correlated with the treatments that had been administered. In order to have two equal groups of 59 and to achieve statistical parity, five students were randomly selected and eliminated from Group II.

For each group (two classes each), a mean score was first obtained for the three tests categorized as Listening Map (LM), No Listening Map (NLM), and a final Comprehensive Test/ Test 3 (See Table 1). The mean scores obtained in Table 1 are shown as a result of using a listening map prior to a test on musical form. The mean score of Group I remained at $\bar{x}=0.81$ for both tests, however Group II scored 0.05 points higher on the test with a listening map shown prior to testing than the test with no listening map. 
Table 1. Mean Scores for Tests

\begin{tabular}{c|l|l|l|l|l|l} 
& LM & NLM & \multicolumn{5}{l}{ Comprehensive Test } \\
\hline & & & 1 & 2 & 3 & 4 \\
\hline Class & & & & & & \\
\hline A & $\bar{x}=0.74$ & $\bar{x}=0.77$ & $\bar{x}=0.96$ & $\bar{x}=0.93$ & $\bar{x}=0.96$ & $\bar{x}=0.88$ \\
\hline B & $\bar{x}=0.88$ & $\bar{x}=0.84$ & $\bar{x}=1.00$ & $\bar{x}=1.00$ & $\bar{x}=0.90$ & $\bar{x}=0.84$ \\
\hline $\begin{array}{c}\text { Group I } \\
\text { TOTAL }\end{array}$ & $\bar{x}=0.81$ & $\bar{x}=0.81$ & $\bar{x}=0.98$ & $\bar{x}=0.97$ & $\bar{x}=0.93$ & $\bar{x}=0.86$ \\
\hline Class & & & & & & \\
\hline C & $\bar{x}=0.87$ & $\bar{x}=0.73$ & $\bar{x}=0.97$ & $\bar{x}=0.97$ & $\bar{x}=0.93$ & $\bar{x}=0.83$ \\
\hline D & $\bar{x}=0.93$ & $\bar{x}=0.97$ & $\bar{x}=1.00$ & $\bar{x}=0.96$ & $\bar{x}=0.82$ & $\bar{x}=0.86$ \\
\hline $\begin{array}{c}\text { Group II } \\
\text { TOTAL }\end{array}$ & $\bar{x}=0.90$ & $\bar{x}=0.85$ & $\bar{x}=0.98$ & $\bar{x}=0.98$ & $\bar{x}=0.88$ & $\bar{x}=0.84$
\end{tabular}

In Table 2 student scores were placed in the chart according to the test number, which each group took in the same order. Group I received the Listening Map treatment before taking Test 1 and Group II did not. For Test $1 \bar{x}=0.81$ for Group I and $\bar{x}=0.85$ for Group II. Prior to Test 2, Group I did not receive instruction with the use of a listening map and Group II did. Group I $\bar{x}=0.81$ remained the same, while Group $\Pi \bar{x}=0.90$ showed 0.05 improvement.

Table 2. Total Group Scores

\begin{tabular}{llll}
\hline & \multicolumn{3}{c}{ Mean Score for Musical Form Tests } \\
\hline & Test 1 & Test 2 & Comprehensive Test \\
\hline Group I & LM & NLM & \\
\multirow{3}{*}{ Group II } & $\bar{x}=0.81$ & $\bar{x}=0.81$ & $\bar{x}=0.94$ \\
& NLM & LM & - \\
& $\bar{x}=0.85$ & $\bar{x}=0.90$ & $\bar{x}=0.92$ \\
\hline
\end{tabular}


A Chi Square $(\chi 2)$ score was obtained in order to compare the two group's scores and also to compare scores while maintaining the position of the variable (listening maps) in the treatments. Table 3 was established in order to organize the data so that the mean scores on each test could be compared. Table 4 is a chart made in order to compare the Comprehensive Test scores of Group I and Group II.

The Chi Square formula was used to compare the total scores of listening maps with no listening maps for Groups I and II. The score $\chi 2=0.0007$ was compared to the Distribution of $\chi^{2}$ (Gay, 2000, p. 620) at a probability $(\alpha)$ of 0.05 and degrees of freedom $(d f)$ of 1 (See Table 5). In order to test for significance the researcher compared the obtained value $(0.0007)$ with the table value $(3.841)$. In as much as $0.0007<3.841$, the hypothesis was rejected and it was concluded that no significance between the two groups' main scores was found.

Treatments 1 and 2 (See Table 3) were compared using the Chi Square formula. The LM in Treatment 1 compared to the NLM in Treatment 2 yielded a $\chi 2=0.005$, a total of 0.0043 larger than the first comparison. In comparison to the Distribution of $\chi 2$ table $0.005<3.841$, therefore no significance was found in the placement of the listening map variable in the lessons. The comprehensive test scores of Groups I and II (See Table 4) were compared, the obtained $\chi 2=0.0002$ is less than 3.841 , the table value, and therefore no significance was found in the comparison of the comprehensive test scores with the placement of the variable. 
The three comparisons of variable placement using $\chi 2$ formula yields the fact that no significance could be found concerning the placement of the listening maps (before and after) with student test scores.

Table 3. Chi Square Chart- Treatment 1 and 2

\begin{tabular}{|c|c|c|c|}
\hline & & & ment \\
\hline & & I & I \\
\hline & I & $\bar{x}=0.81$ & $\bar{x}=0.81$ \\
\hline roup & II & $\bar{x}=0.90$ & $\bar{x}=0.85$ \\
\hline
\end{tabular}

Table 4. Chi Square Chart- Comprehensive Test

\begin{tabular}{|l|l|}
\multicolumn{1}{c}{ I } \\
\hline $\bar{x}=0.81$ & $\bar{x}=0.85$ \\
\hline
\end{tabular}

Table 5. Chi Square Obtained Scores and Distribution of Chi Square

\begin{tabular}{lcc}
\hline \multicolumn{1}{c}{ Comparison } & $\chi 2$ & Distribution of $\chi^{2}$ \\
\hline LM Total Score vs. NLM & & $\alpha=0.05 \mathrm{df}=1$ \\
Total Score & $=0.0007$ & 3.841 \\
LM Treatment 1 vs. & & $\alpha=0.05 \mathrm{df}=1$ \\
NLM Treatment 2 & $=0.005$ & 3.841 \\
Comprehensive Test & & $\alpha=0.05 \mathrm{df}=1$ \\
Group I vs. Group II & $=0.0002$ & 3.841 \\
\hline
\end{tabular}


A Sign Test was performed to compare the "direction of difference between two scores of a series of matched scores" (Madsen \& Madsen, 1997, p. 107). That is, $a+$ or - was substituted for correct or incorrect answers. The scores of each group on the test that was given after instruction with the use of a listening map are placed in Table 6.

Table 7 shows the obtained sign test value (z) given for the comparison of the two groups, I and II is $\mathrm{z}=0.40$. When comparing the scores of a one-tailed test, one in which a prediction as to the direction of the scores was made prior to the study, the obtained score is compared to the probability score found in $\mathrm{z}$ score table (Seigle, 1956). The hypothesis of this study predicted that students' understanding of musical form would increase after receiving the listening map treatment.

The obtained score $\mathrm{z}=0.40$ was compared to the $p$ of the $\mathrm{z}$ table value (0.3264). In as much as $0.40 \geq 0.3264$, it is significantly different from the total value and therefore LM scores were significantly higher than NLM scores. This hypothesis for this study was accepted.

Table 6. Sign Test Comparison Chart

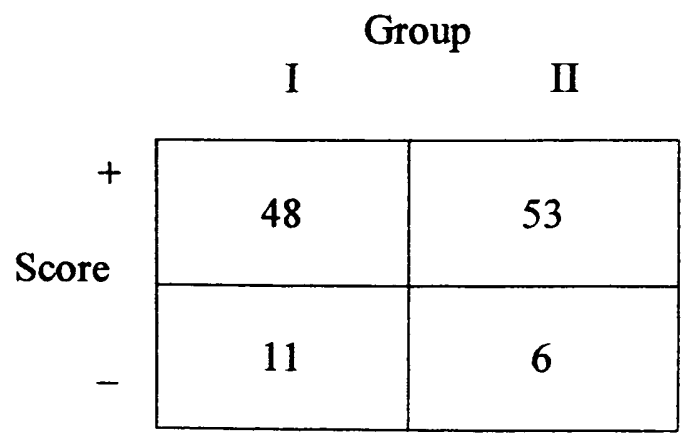


Table 7. $\underline{\text { Sign Test Scores }}$

\begin{tabular}{|c|c|c|}
\hline Sign Test & $\mathbf{z}$ & $\begin{array}{l}\text { One-Tailed } \\
p \text { of } \mathrm{z} \text { score }\end{array}$ \\
\hline Treatment 1 vs. Treatment 2 & & $\alpha=0.05$ \\
\hline Amount of + answers & $=0.40$ & $\begin{array}{l}p \text { of } \mathrm{z}= \\
0.3264\end{array}$ \\
\hline
\end{tabular}

The comparison made by the Sign Test was that of the test scores of Group I and Group II after they each had received the variable of listening maps during instruction. Significance was found using the Sign Test because the intended scores on the tests were being compared to the mean. The results of the Chi Square formula show that the order in which the variable was presented did not matter. Based upon the results of this study when the variable was placed in the unit does not matter, but student understanding of musical form will increase when a map is used.

After both treatments and tests had been administered to Groups I and II an Affective Questionnaire was given to both groups. The mean scores for each question on the survey are shown in Table 8. Another hypothesis for this study predicted that listening maps would help to increase preference for orchestral music. Question \# 1 refers to Tchaikovsky's "March". In this lesson, Group II received instruction with the listening map Group I did not. The preference $\bar{x}$ for $($ ) in question \#1 (See Table 8) for Group I was $\bar{x}=0.85$ and Group II was $\bar{x}=0.89$. The preference $\bar{x}$ for $\otimes$ in question \#1 for Group II was $\bar{x}=0.00$ and for Group I $\bar{x}=0.02$. In the survey, Question \#5 referred to Saint-Saens" "The Aquarium", in this lesson Group I received instruction with a listening map and Group $\Pi$ did not. The preference $\bar{x}$ for $($ ) for 
Question \#5 in Group I was $\bar{x}=0.77$ and Group II $\bar{x}=0.75$. The preference $\bar{x} \otimes$ for Question \#5 the results in Group II were $\bar{x}=0.07$ and in Group I $\bar{x}=0.04$. In both questions \#1 and \#5 the students who used the listening map preferred the music to the group who did not receive the listening map.

In Question \#4, the preference $\bar{x}$ for $(:)$ in Group $I I$ (which used listening maps) was 0.93 and Group I $\bar{x}=0.82$. More students in Group II expressed an interest in wanting to hear more songs like the "March" than in Group I. In question \#8 students in Group II (no listening map during instruction) expressed the following preference $\bar{x}: \Theta=0.77, \odot=0.08$, and $\Theta=0.15$. However, Group I (received instruction with listening maps) results for question $\# 8$ were $\bar{x}: \odot=0.70, \Theta=0.16$, and $\Theta=0.14$. The results for questions 4 and 8 seem to show that when using a listening map students are more willing to listen to a similar piece of music at a later time.

Both groups preferred listening to music with a listening map to follow and showed interest in following more maps in the future. When asked in question \#9 if they liked to follow the listening maps Group I preference $\bar{x}$ for $(-)$ was 0.82 and Group II $\vec{x}$ for $(-)$ was 0.83 . Question \#10 was in reference to the students desire to follow a listening map for more music. The results in this case for preference $\bar{x} \odot$ in Group I were 0.80 and in Group II preference $\bar{x}$ :) was 0.79 .

In conclusion, the affective questionnaire that was given to the students following the treatments supports the prediction made prior to the study. Students do 
prefer listening to orchestral music when using a music listening map. Results show that approximately 0.80 of the students questioned enjoyed following a listening map and would like to do so again.

Table 8. Affective Questionnaire

\begin{tabular}{|c|c|c|}
\hline \multicolumn{3}{|c|}{ Affective Questionnaire $\bar{x}$} \\
\hline Question & I & $\overline{\mathbf{I}}$ \\
\hline \multirow{4}{*}{$\begin{array}{l}\text { 1. Check the face that looks the } \\
\text { way you liked the "March". }\end{array}$} & $\begin{array}{l}\text { (;) } \\
0.85\end{array}$ & $\begin{array}{l}\text { (i); } \\
089\end{array}$ \\
\hline & $\overbrace{012}$ & (2) \\
\hline & (2) & (2) \\
\hline & 0.02 & 0.00 \\
\hline \multirow{5}{*}{$\begin{array}{l}\text { 2. Check the face that looks like } \\
\text { you if you want to hear the } \\
\text { "March" again. }\end{array}$} & (i) & (;) \\
\hline & 0.85 & 0.80 \\
\hline & $\begin{array}{l}\odot \\
0.07\end{array}$ & (-) \\
\hline & (2) & (2) \\
\hline & 0.07 & 0.19 \\
\hline \multirow{5}{*}{$\begin{array}{l}\text { 3. Check the face that looks like } \\
\text { you if you liked the rhythm of the } \\
\text { "March". }\end{array}$} & (:) & (-) \\
\hline & 0.82 & 0.77 \\
\hline & 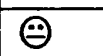 & $\odot$ \\
\hline & 0.15 & 0.22 \\
\hline & $\begin{array}{l}0 \\
0.04\end{array}$ & $\begin{array}{l}\text { Q } \\
\mathbf{0 . 0 2}\end{array}$ \\
\hline \multirow{5}{*}{$\begin{array}{l}\text { 4. Check the face that looks like } \\
\text { you if you want to hear another } \\
\text { song like the "March". }\end{array}$} & (:) & (-) \\
\hline & 0.82 & 0.93 \\
\hline & $\begin{array}{l}\oplus \\
\mathbf{0 . 1 1}\end{array}$ & $\begin{array}{l}\stackrel{\ominus}{0} \\
0.06\end{array}$ \\
\hline & (2) & (2) \\
\hline & 0.07 & 0.02 \\
\hline \multirow{5}{*}{$\begin{array}{l}\text { 5. Check the face that looks like } \\
\text { you if liked "The Aquarium" } \\
\text { from the previous lesson. }\end{array}$} & (:) & (;) \\
\hline & 0.77 & 0.75 \\
\hline & $\begin{array}{l}\stackrel{;}{0.20} \\
0.07\end{array}$ & $\begin{array}{l}\text {;) } \\
0.19\end{array}$ \\
\hline & 2 & 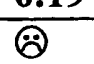 \\
\hline & 0.04 & 0.07 \\
\hline
\end{tabular}




\begin{tabular}{|c|c|c|}
\hline \multirow{3}{*}{$\begin{array}{l}\text { 6. Check the face that looks like } \\
\text { you if you want to hear "The } \\
\text { Aquarium" again. }\end{array}$} & $\begin{array}{l}\text { (-) } \\
0.71\end{array}$ & $\begin{array}{l}\text { (:) } \\
0.69\end{array}$ \\
\hline & $\stackrel{\theta}{\theta}$ & $\begin{array}{l}-\theta \\
019\end{array}$ \\
\hline & $\begin{array}{l}\text { (2) } \\
0.14\end{array}$ & $\begin{array}{l}\text { (2) } \\
0.13\end{array}$ \\
\hline \multirow{3}{*}{$\begin{array}{l}\text { 7. Check the face that looks like } \\
\text { you if you liked the rhythm of the } \\
\text { "The Aquarium". }\end{array}$} & $\begin{array}{l}\text { (i) } \\
0.77\end{array}$ & $\begin{array}{l}\text {;) } \\
0.69\end{array}$ \\
\hline & $\begin{array}{l}\stackrel{-}{0.14} \\
0.14\end{array}$ & $\begin{array}{l}\stackrel{\ominus}{0.26} \\
0.09\end{array}$ \\
\hline & $\begin{array}{l}\text { :) } \\
\mathbf{0 . 0 9}\end{array}$ & $\begin{array}{l}\text { : } \\
0.06\end{array}$ \\
\hline \multirow{3}{*}{$\begin{array}{l}\text { 8. Check the face that looks like } \\
\text { you if you want to hear another } \\
\text { song like "The Aquarium". }\end{array}$} & $\begin{array}{l}\text { () } \\
0.70\end{array}$ & $\begin{array}{l}\text { (;) } \\
0.77\end{array}$ \\
\hline & $\begin{array}{l}\Theta \\
0.16\end{array}$ & $\begin{array}{l}\ominus \\
0.08\end{array}$ \\
\hline & $\begin{array}{l}\text { (2) } \\
0.14\end{array}$ & $\begin{array}{l}\text { : } \\
0.15\end{array}$ \\
\hline \multirow{3}{*}{$\begin{array}{l}\text { 9. Check the face that looks like } \\
\text { you if you like to follow music } \\
\text { listening maps. }\end{array}$} & $\begin{array}{l}\text { (;) } \\
0.82\end{array}$ & $\begin{array}{l}\text { (;) } \\
0.83\end{array}$ \\
\hline & $\begin{array}{l}\stackrel{\ominus}{\mathbf{0 . 1 3}} \\
\end{array}$ & $\begin{array}{l}-\oplus \\
\mathbf{0 . 0 8}\end{array}$ \\
\hline & $\begin{array}{l}\text { : } \\
0.05\end{array}$ & $\begin{array}{l}\text { : } \\
0.09\end{array}$ \\
\hline \multirow{3}{*}{$\begin{array}{l}\text { 10. Check the face that looks like } \\
\text { you if you want to follow a } \\
\text { listening map for more music. }\end{array}$} & $\begin{array}{l}\text { (i) } \\
0.80\end{array}$ & $\begin{array}{l}\text { (;) } \\
0.79\end{array}$ \\
\hline & $\begin{array}{l}\stackrel{\ominus}{0} \\
\mathbf{0 . 1 1}\end{array}$ & $\begin{array}{l}\ominus \\
0.05\end{array}$ \\
\hline & $\begin{array}{l}\text { (2) } \\
0.09\end{array}$ & $\begin{array}{l}\text { (2) } \\
0.16\end{array}$ \\
\hline
\end{tabular}




\section{Discussion}

It was hypothesized prior to this study, that the use of music listening maps would increase the learning and preference of $2^{\text {nd }}$ grade students for classical and romantic music of the $18^{\text {th }}$ and early $19^{\text {th }}$ centuries. Music listening maps were used as the variable in this research to teach and assess music listening activities in the music classroom. A listening map is a pictorial graph that can be followed by students while listening to a recording of music (Appendix A and B).

Music educators are constantly looking for ways to help students learn about serious music and for ways to keep them interested in music over a period of time. In today's society music written in the classical and romantic style of the $18^{\text {th }}$ and early $19^{\text {th }}$ centuries is not often commonly heard. In order to help students understand and appreciate this genre of music, which sometimes seems so foreign, it would seem that it needs to be presented in school music classes. Often, when music educators use orchestral music at all, they do so as a passive activity where students are asked to simply sit quietly and listen (Fallis, 1996; Reimer, 1997). The results of this research point to the fact that students need to be actively engaged in the subject matter in order to better understand and enjoy it.

This research was a curriculum-based study. It was designed to investigate one aspect of the traditional curriculum and one of the newest innovations in curriculum to see if it is a viable alternative to the tradition of sitting and listening. One of the goals for music educators that have been set forth by the state of Florida in the Sunshine State Standards is music history and appreciation. Likewise, in the Competency 
Based Curriculum that has been designed as a curriculum guide for the music teachers of Miami Dade County, students are expected to learn and understand different genres of music and how they are constructed. The MacMillian/McGraw Hill Share the Music textbook series (1997) is designed to meet the needs of both these State and Local goals in an innovative way that students will enjoy. In this study the use of listening maps, supplied by this textbook series, was tested to see if students learn more and enjoy orchestral music more when it is presented in a hands-on setting.

Often music educators find themselves looking for the 'best' way to teach a lesson and to keep the students involved. This study was designed to investigate whether or not instruction with music listening maps concerning musical form (AB and ABA) would increase students' interest for serious music and also to determine if instruction with the use of listening maps would help increase student learning as measured by test scores.

The study was designed to last for 3 consecutive music classes. Each of the three classes were taught using the same lesson plan consisting of two separate treatments that were given in the form of a music history lesson on $A B$ and $A B A$ form. Each of the two treatments were followed with a test where as in the third class students were given a final review followed by a comprehensive test. During Treatment 1, Group I received instruction on $\mathrm{AB}$ form for "The Aquarium" by Saint Saens including the use of a music listening map, while Group II received the same lesson without a listening map. At the conclusion of the first treatment both groups 
were administered Test 1 in order to assess their ability to identify AB form visually. During Treatment 2,

Group I received instruction on ABA form using the "March" from The Nutcracker Suite by Tchaikovsky without the use of a music listening map and Group II received the same lesson using a music listening map. At the conclusion of the second treatment both groups were given Test 2 in order to assess their ability to identify ABA form visually. Following Test 2 an Affective Survey was administered to both groups in order to assess the students' preference for the different music activities and whether or not they enjoyed using music listening maps. During the third class of this research students were given a brief review of musical forms $A B$ and ABA. At the end of the review students took a comprehensive test (Test 3) in order to assess their ability to identify the two different musical forms.

The sample for this study was taken from four classes of $2^{\text {nd }}$ grade students at a Miami Dade County Public School located in Homestead, Florida. Although all six second grade classes received the experimental treatments, four out of the six classes in the school were selected to participate in this curriculum-based research. The four classes (A, B, C, and D) of normal students were randomly divided into two groups (I and II). Originally each group consisted of approximately 68 students, however, eighteen students were eliminated due to absence from either Treatment 1 and/or Treatment 2. Five more students were randomly excluded from Group II so that Group I and Group II would each consist of 59 students. 
In order to evaluate the test scores in this study a Chi Square $(\chi 2)$ procedure and a Sign Test were used to determine whether or not the hypothesis should or should not be rejected. A $\chi^{2}$ value was obtained (Gay, 2000) in order to determine if significance exists in the placement of the music listening map variable during instruction. A Sign Test (Seigle, 1956) was used to compare individual test scores of students after they had received the music listening map instrument to determine if it makes a significant difference. Individual responses on the Affective Survey were evaluated by looking at Mean $(\bar{x})$ scores for each response. The $\bar{x}$ scores of each group on this affective assessment were then compared to determine if listening maps increase student preference for classical and romantic music.

Total scores of classes using listening maps with scores of classes using no listening maps prior to the test were compared for both groups using the $\chi 2$ formula. After comparing the obtained value with the table value at the probability of 0.05 the hypothesis was rejected because $0.0007<3.841$ (Gay, 2000, p.620). The $\chi^{2}$ procedure was also used to compare the use of listening maps prior to the test with no listening maps prior to the test. The obtained value compared to the distribution of $\chi 2$ table value was $0.005<3.841$. No significance was found between the comprehensive test scores and the placement of the variable because $0.0002<3.841$. The results show that no significance was found between the placements of listening maps instrument prior to a test on musical form, or, stated another way, it does not matter which treatment was presented first. 
A Sign Test procedure was used to evaluate individual student scores on the post-test after each student had received the listening map instrument. Then a determination could be made as to whether or not music listening maps create a significant difference in student scores. The obtained Sign Test (z) value for the comparison of the two groups in the research was $z=0.40$. This obtained score was significantly larger than the table value with the probability $0.05,(0.40>0.3264)$. This Sign Test shows that listening maps will help students to perform better when learning musical form.

The results of the Affective Survey based on the $\bar{x}$ score for each question showed students preferred the music more when listening maps were used during the lesson. Most students responded with a willingness to listen to similar music if listening maps were used. The majority of the students expressed that they liked to follow listening maps and would like them incorporated into future lessons.

According to the results of this study, the placement of the variable (listening map) in a lesson does not matter. However, the Sign Test procedure makes it clear that when a listening map is presented during the lesson more students will pass a test about musical form than will those without its use. Results also show that students prefer to listen to classical and romantic music when a listening map is available to follow. If teaching tools such as music listening maps help students to better understand music history lessons and to even like the music being taught, it would seem that they are worth using. 
It is possible that had the groups not been counterbalanced, an even larger difference would have been seen in the results of the $\mathrm{AB}$ test and $\mathrm{ABA}$ test. In retrospect, it is also possible that if one group had not received any instruction with listening maps, results might have been more pronounced. In future designs of a similar research, a control could be established in which no listening maps would be administered and an experimental group to receive the listening map variable. However, by counterbalancing these variables all children received both treatments, and no one was left with an "inferior" experience. The results of this research showed that counterbalancing is not necessary, because no significant difference or order effect was found. Therefore, it might be beneficial to future researchers to know that adding counterbalancing to the design adds nothing.

Research concerning music preferences and music appreciation of young children is investigated rather often, as reported in the literature (Brittin, 2000; Cotter, et al, 1971; Fallis, 1996; Geringer, 1982; Greer, et al, 1974; LeBlanc 1981, 1983, 1995; McGirr, 1994; Reimer, 1997; Samaroff- Stokowksi, 1996; Shehan-Campbell, 1983, 1985; Sims, 1990; Webster, et al, 1993). However, there are very few studies in the area of music listening maps and other ways to actively involve students to increase preference and appreciation (Arts Education IDEAS, 2001; Dunn, 1997; Hildebrandt, 1998; Kaschub, 1997; Waterfall, 1995). Many music educators are not aware of the different tools that can be used to guide and help music students in the classroom. As music educators, we need to try and keep our music heritage alive. It needs to be a part of the lives of all young children. With active listening lessons 
knowledge is gained and an appreciation is built. When our students hear musical works that they learned about in school and they can identify them by composer and share their excitement with friends and family, then we have done our jobs. More research needs to be accomplished to help music educators better determine instructional methods and resources that work best for building student knowledge and interest. 
Arts Education IDEAS. (n.d.). Listening Maps. Retrieved September 22, 2001, from http://www.aeideas.com/listeningmaps.html

Brittin, R.V. (2000). Children's preference for sequenced accomplishments: The influence of style and perceived tempo. Journal of Research in Music Education, 48 (3), 237-248.

Cotter, V.W., \& Spardlin, J.E. (1971). A nonverbal technique for studying music preference. Journal of Experimental Child Psychology, 11 (2), 357-365.

Davidson College, North Carolina, Classical 89.9 Music Listening Journal. (n.d.).

15 Creative listening adventures. Retrieved September 25, 2001, from the Classical 89.9 Website: http://www.wdav.org/mymusicjournal/intro2.html

Dunn, R.E. (1997). Creative thinking and music listening [Electronic Version]. Research Studies in Music Education, 8, 1-16.

Fallis, T.L. (1996). Music appreciation: a living approach. Teaching Music, 3 (5), 32-33.

Gay, L.R. (2000). Educational research competencies for analysis and application. Upper Saddle River, NJ: Prentice-Hall, Inc.

Geringer, J.M. (1982). Verbal and operant music listening preferences in relationship to age and musical training. Psychology of Music, Special Issue, 47-50.

Greer, R.D., Dorow, L.G., Randall, A. (1974). Music listening preferences of elementary school children. Journal of Research in Music Education, 22 (4), 284-291.

Greer, R.D., Dorow, L.G., Wachhaus, G., \& White, E.R. (1973). Adult approval and students music selection behavior. Journal of Research in Music Education, 21 (4), 345-354.

Hildebrandt, C. (1998). Creativity in music and early childhood. Young Children, $53(6), 68-74$.

Johnson, C.L. (1990). From print to practice: making research work for you. Music Educators Journal, 77(3), 41-45.

Kaschub, M. (1997). Exercising the musical imagination. Music Educators Journal, 84 (3), 26-32, 
LeBlanc, A. (1979). Generic style music preferences of fifth-grade students. Journal of Research in Music Education, 27 (4), 255-270.

LeBlanc, A. (1981). Effects of style, tempo, and performing medium on children's music preference. Journal of Research in Music Education, 29 (2), 143-156.

LeBlanc, A. (1983). Broaden students' music preferences. Music Educators Journal, 69 (7), $47-48$

LeBlanc, A. (1995). Differing results in research on preference for music tempo. Perceptual and Motor Skills, 81, 1253-1254.

LeBlanc, A., Sims, W.L., Siivola, C., \& Obert, M. (1996). Music style preferences of different age listeners. Journal of Research in Music Education, 44 (1), 49-59.

MacMillan/McGraw-Hill, Inc. (n.d.). Listening. Retrieved September 25, 2001, from http://www.mmhschool.com/parent/music/sharethemusic/listening.html

Madsen, C. K. \& Madsen, C. H. (1998). Teaching/discipline a positive approach for educational development. Raleigh, NC: Contemporary Publishing Company of Raleigh, Inc.

Madsen, C.K. \& Madsen, C.H. (1997). Experimental research in music ( $3^{\text {rd }}$ ed.). Raleigh, NC: Contemporary Publishing Company.

McGirr, P.I. (1994). Verdi invades the kindergarten. Childhood Education, 71 (2), 74-79.

National Association for the Education of Young Children. (1997). Music appreciation: $A$ universal language for all ages. Early years are learning years. Retrieved September 25, 2001 from http://npin.org/library/pre1998/n00236/n00236.html

Petzold, R.G. (1963). The development of auditory perception of musical sounds by children in the first six grades. Journal of Research in Music Education, 11(1), 21-43.

Petzold, R.G. (1969). Auditory perception by children. Journal of Research in Music Education, 17 (1), 82-87.

Reimer, B. (1997). Music education in the twenty-first century. Music Educators Journal, 84 (3), 33-38. 
Rogers, V.R. (1957). Children's musical preferences as related to grade level and other factors. Elementary School Journal, 11, 433-435.

Samaroff-Stokowski, O. (1996). Educating the listener. American Music Teacher, 46, 26-29.

Seigle, S. (1956). Nonparametric statistics for the behavioral sciences. New York: McGraw-Hill Series in Psychology, Hill Book Company.

Share The Music (1997). New York, NY: MacMillan/McGraw-Hill School Publishing Company.

Shehan-Campbell, P. K. (1983). Student preferences for ethnic music styles. Contributions to Music Education, 9, 20-27.

Shehan-Campbell, P.K. (1985). Transfer of preference from taught to untaught pieces of non-western music genres. Journal of Research in Music Education, 33 (3) 149-158.

Sims, W.L. (1990). Sound approaches to elementary music listening. Music Educators Journal, 77 (4), 38-42.

Waterfall, M. (1995). "Gulliver's travels" by Alfred Silver with music by Stephen Naylor. (Report No. RIESEP1995). Washington, DC: John F. Kennedy Center for the Performing Arts. (ERIC Document Reproduction Service No. ED381842)

Webster, P., \& Richardson, C. (1993). Asking children to think about music [Electronic Version]. Arts Education Policy Review, 94, 7-11.

Weinberger, N.M. (1998, Spring). Creating creativity with music [Electronic Version]. Musica Research Notes, 5 (2), 1-4.

Woody, R.H., \& Burns, K.J. (2001). Predicting music appreciation with past emotional responses to music. Journal of Research in Music Education, 49 (1), 57-70. 
1 symbol
$=1$ measure of

March from The Nutcracker

by Piotr Ilyich Tihuikorshy.

A)

This instructional resource was provided in the MacMillan/McGraw-Hill Share the Music textbook. This textbook series is a part of the music curriculum at the school in which this study took place. 
The Aquarium from

The Carnival of the Animals

by Camille Saint-Sä̈ns

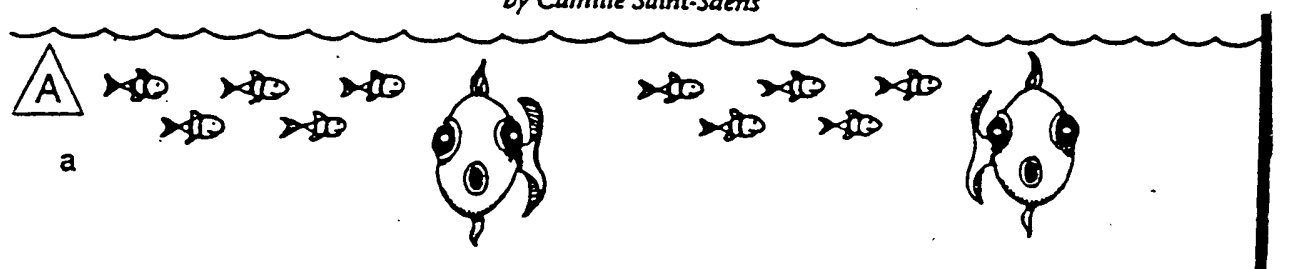

b
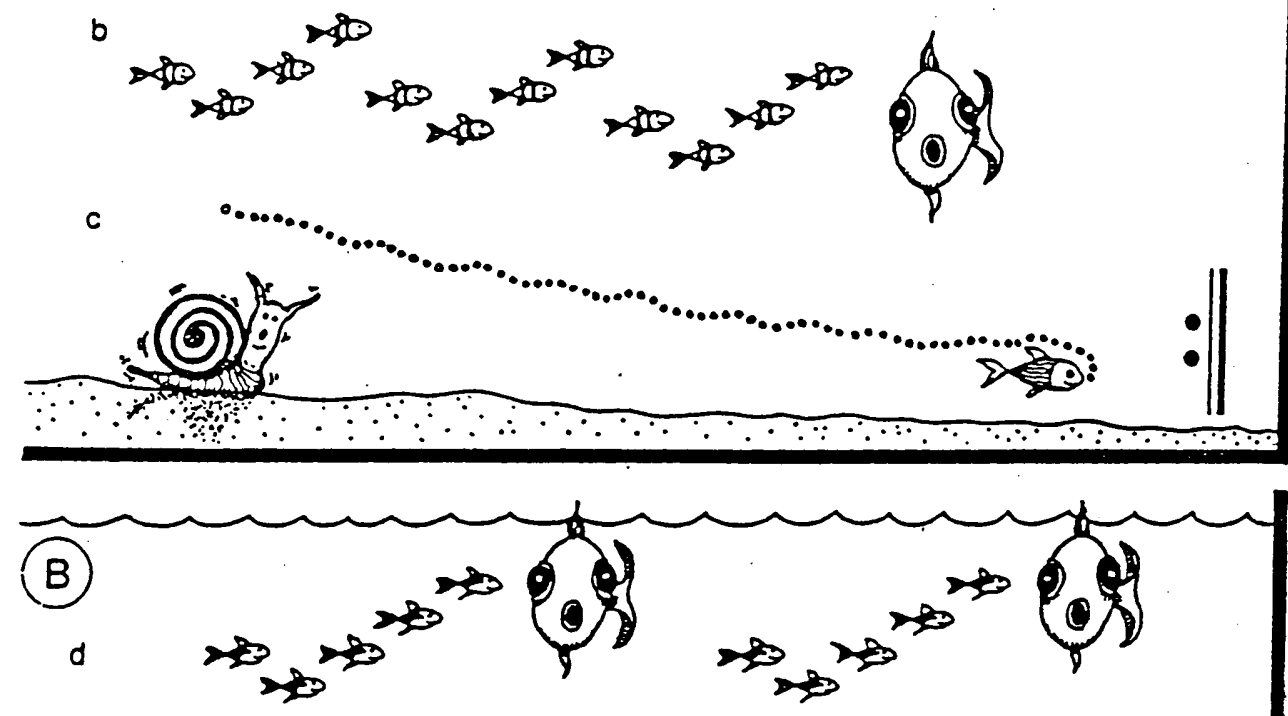

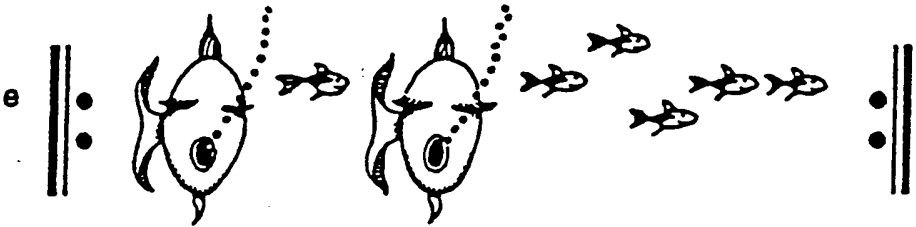

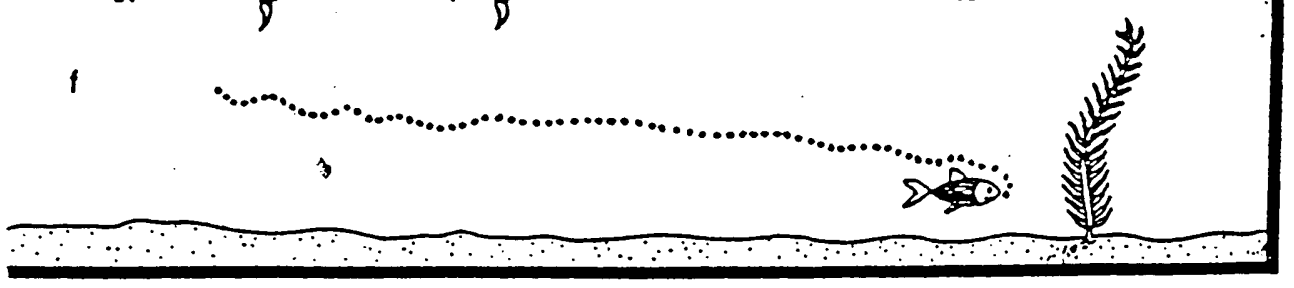

This instructional resource was provided in the MacMillan/McGraw-Hill Share the Music textbook. This textbook series is a part of the music curriculum at the school in which this study took place. 
Questions to be read by teacher:

1) Write the letter " $A$ " next to the symbol that is the beginning of the A section.

2) Write the letter " $B$ " next to the symbol that is the beginning of the B section.

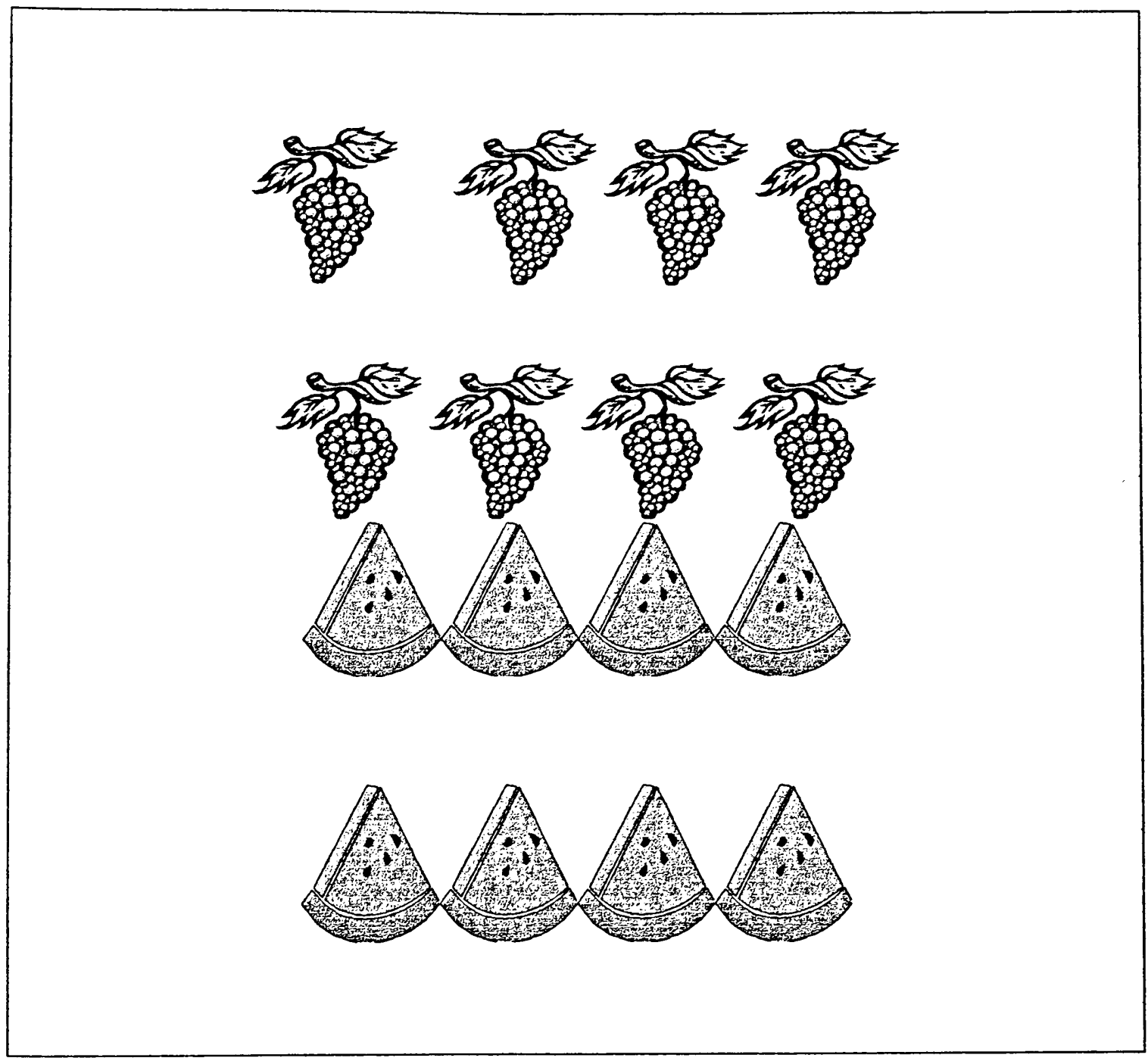


Questions to be read by teacher:

\section{Test 2- ABA Form}

1) Write the letter " $A$ " next to the symbol that is the beginning of the FIRST A section.

2) Write the letter " $B$ " next to the symbol that is the beginning of the B section.

3) Write the letter " $A$ " next to the symbol that is the beginning of the SECOND A section.

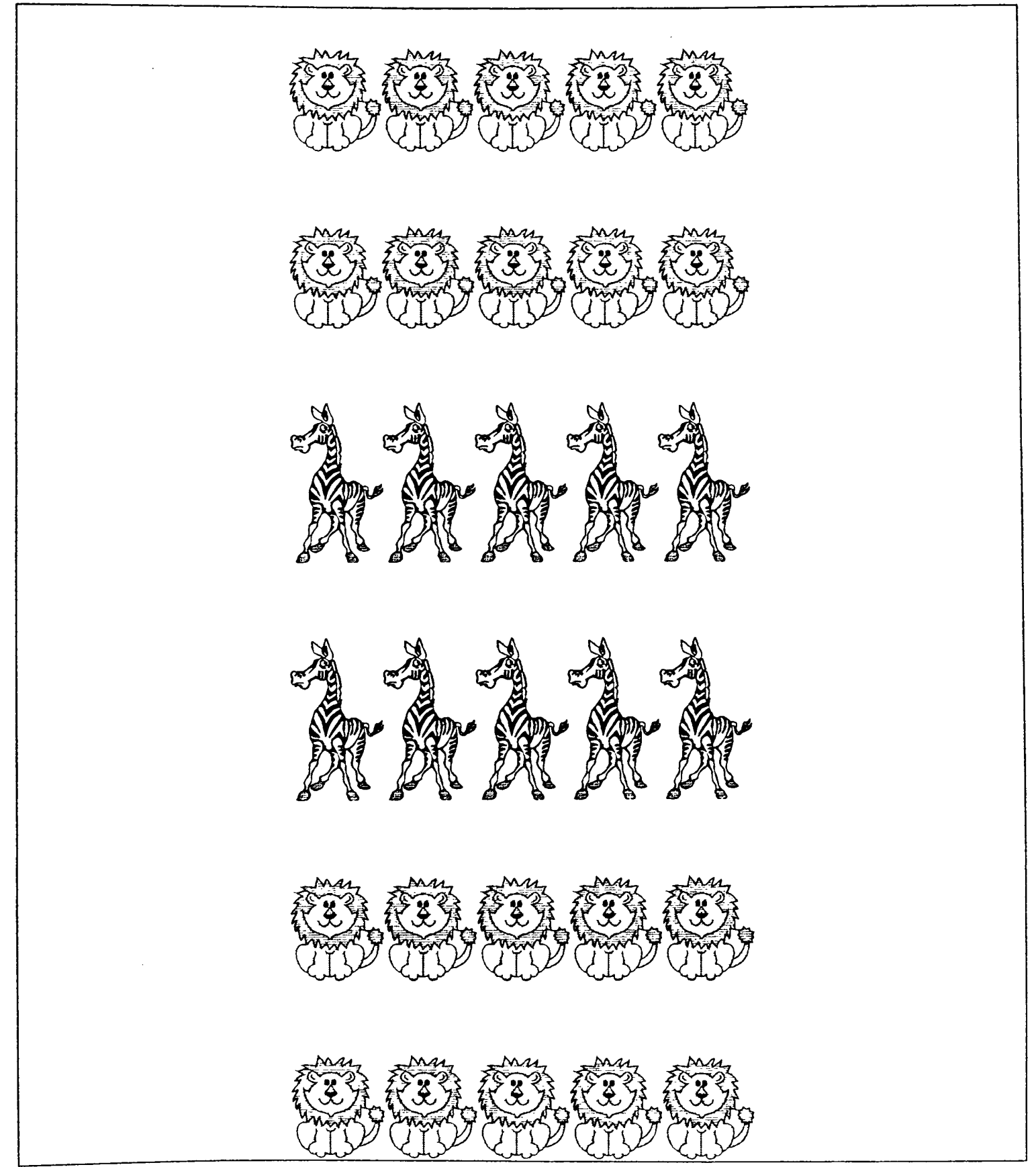


Appendix E

Test 3- Comprehensive Test

Questions to be read by teacher:

1) Identify the Musical Form of the following objects. Write the letters $A B$ or $A B A$ in the blank to indicate the form.

Answer:

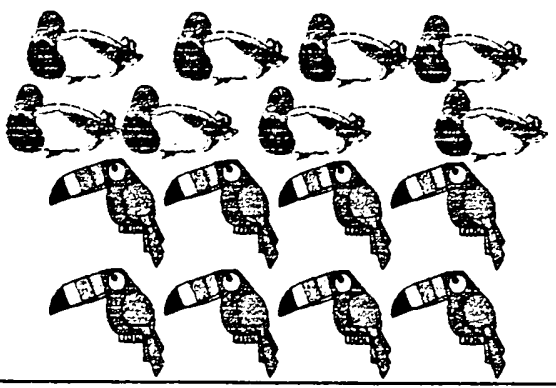

2) Identify the Musical Form of the following objects. Write the letters $A B$ or $A B A$ in the blank to indicate the form.

Identify the Musical Form of the following objects as $\mathrm{AB}$ or $\mathrm{ABA}$.

Answer:
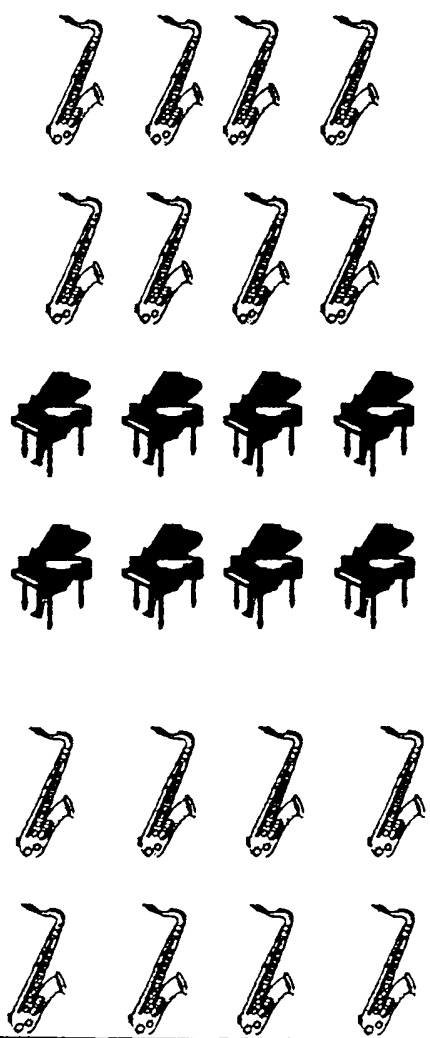
3) Write the letter " $A$ " next to the symbol that is the beginning of the A section.

4) Write the letter " $B$ " next to the symbol that is the beginning of the B section.

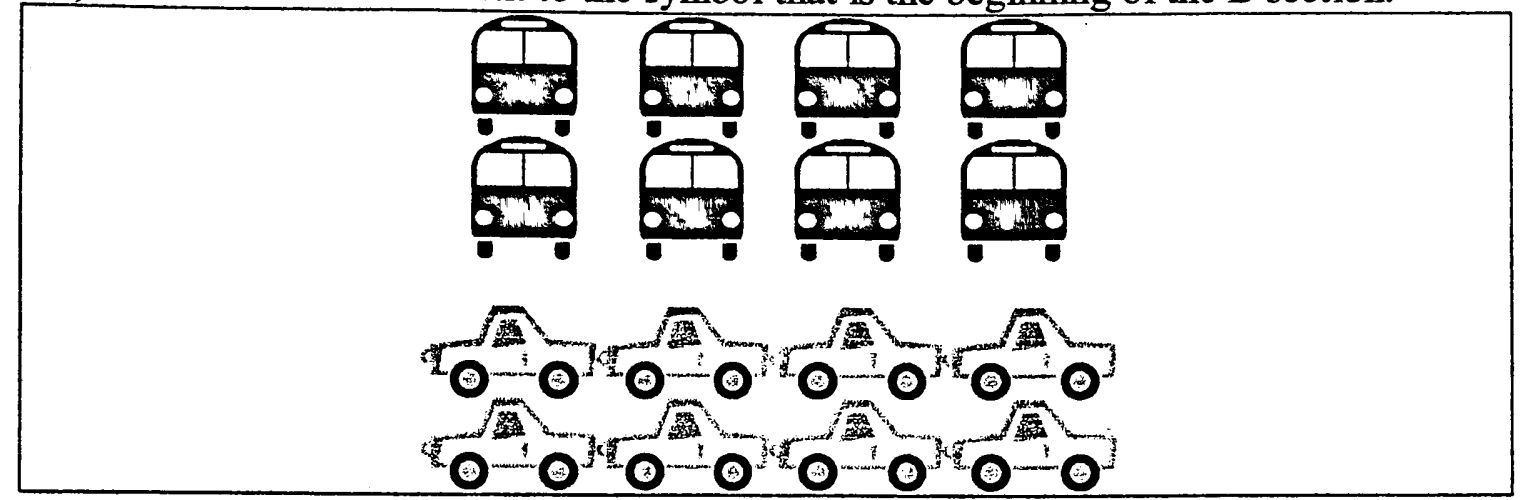

5) Write the letter " $A$ " next to the symbol that is the beginning of the FIRST A section.

6) Write the letter " $\mathrm{B}$ " next to the symbol that is the beginning of the B section.

7) Write the letter " $A$ " next to the symbol that is the beginning of the SECOND A section.

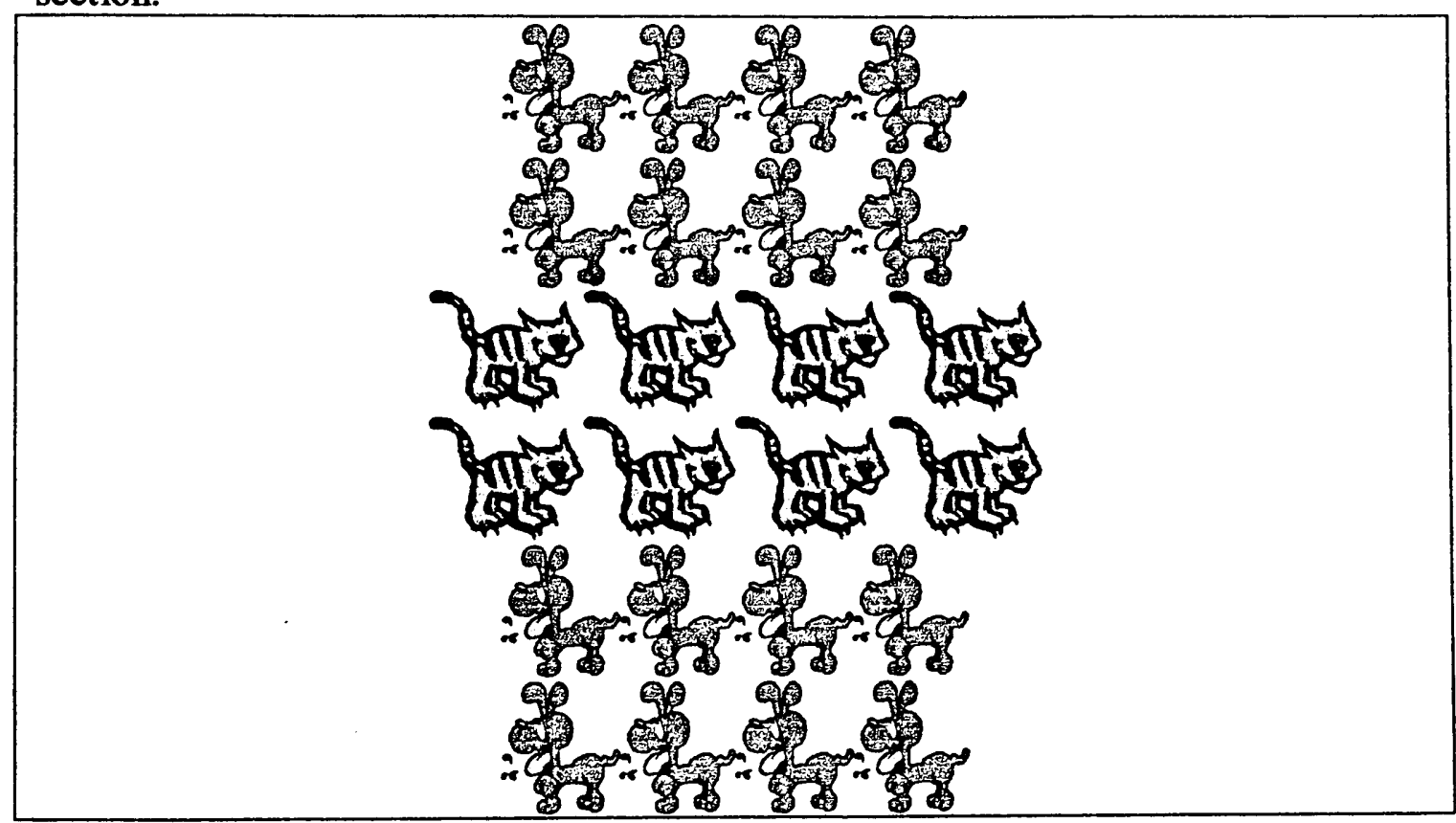




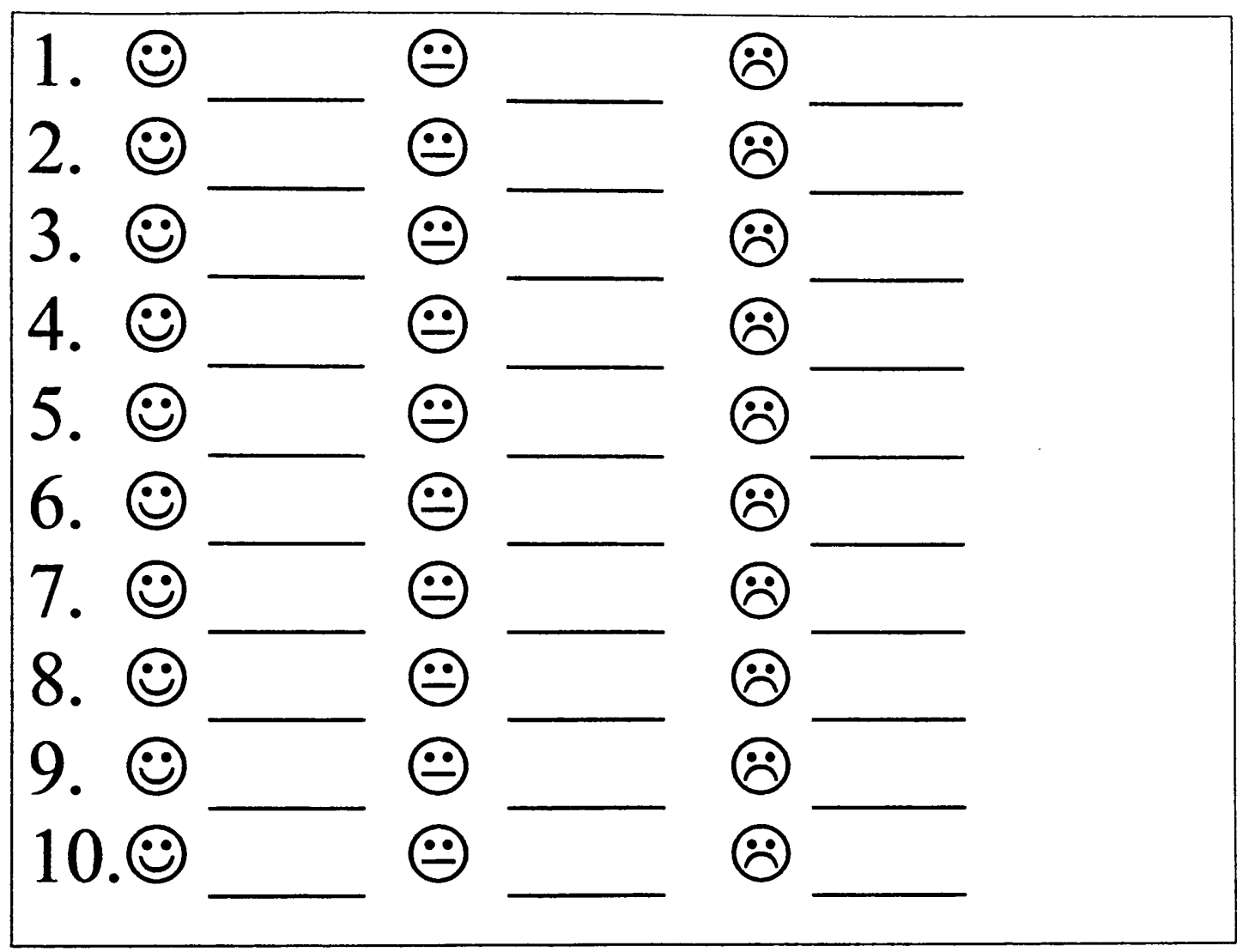

Directions: Each question as 3 possible answers. Choose the best one each time that answers the question that I ask you.

1. Check the face that looks the way you liked the "March".

2. Check the face that looks like you if you want to hear the "March" again.

3. Check the face that looks like you if you liked the rhythm of the "March".

4. Check the face that looks like you if you want to hear another song like the "March".

5. Check the face that looks like you if liked "The Aquarium" from the previous lesson.

6. Check the face that looks like you if you want to hear "The Aquarium" again.

7. Check the face that looks like you if you liked the rhythm of the "The Aquarium".

8. Check the face that looks like you if you want to hear another song like "The Aquarium".

9. Check the face that looks like you if you like to follow music listening maps.

10. Check the face that looks like you if you want to follow a listening map for more music. 
Objectives: \\ Treatment \#1 Lesson Plan}

1. Student will be able to visually identify $A B$ form.

2. Student will be able to listen to and understand "The Aquarium" form Carnival of the Animals by Saint-Saens.

3. Student will be able to learn basic historical facts about Saint-Saens. (Enrichment)

Materials: Picture of Saint-Saens, MacMillan series CD for "The Aquarium", Music Listening Map (Only for group IB and IIA), AB post-test, Stereo, Pencils, Overhead Projector.

Procedures:

Groups IB and IIA

1. Teacher will introduce the biography of Saint-Saens to students.

2. Teacher will explain the form AB. Students will practice grouping symbols into $\mathrm{AB}$ form with teacher on the board.

3. Teacher will introduce "The Aquarium" to students. Students will listen one time to a CD recording.

4. Teacher will pass out listening maps to students. Teacher will discuss map with students: form, pitch direction, repeat sign.

5. Teacher will use overhead projector to guide students through the selection with the map the first time.

6. Students will listen two more times following the map independently.

Groups IA and IIB

1. Teacher will introduce the biography of Saint-Saens to students.

2. Teacher will explain the form AB. Students will practice grouping symbols into $A B$ form with teacher on the board.

3. Teacher will introduce "The Aquarium" to students. Students will listen one time to a $\mathrm{CD}$ recording.

4. Teacher will discuss form and pitch direction of the piece.

5. Students will listen 2 more times, trying to identify the A section and B section.

Assessment: Student will take AB form Post-Test. 


\section{The Aquarium from}

The Carnival of the Animals

by Camille Saint-Saëns

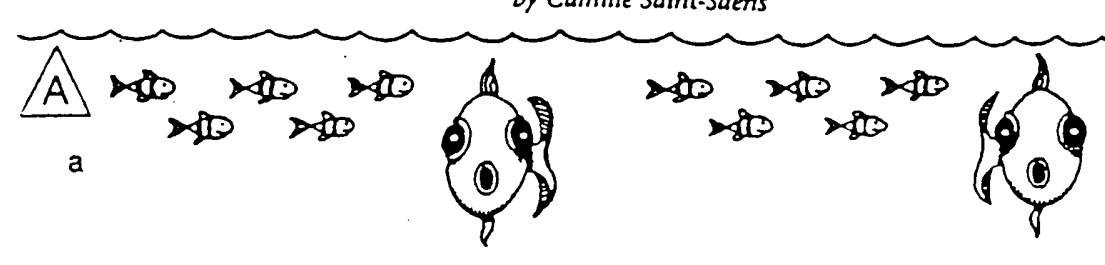

b

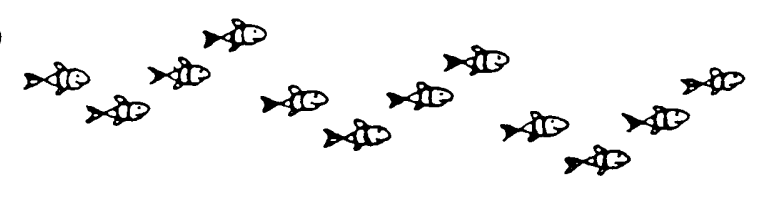
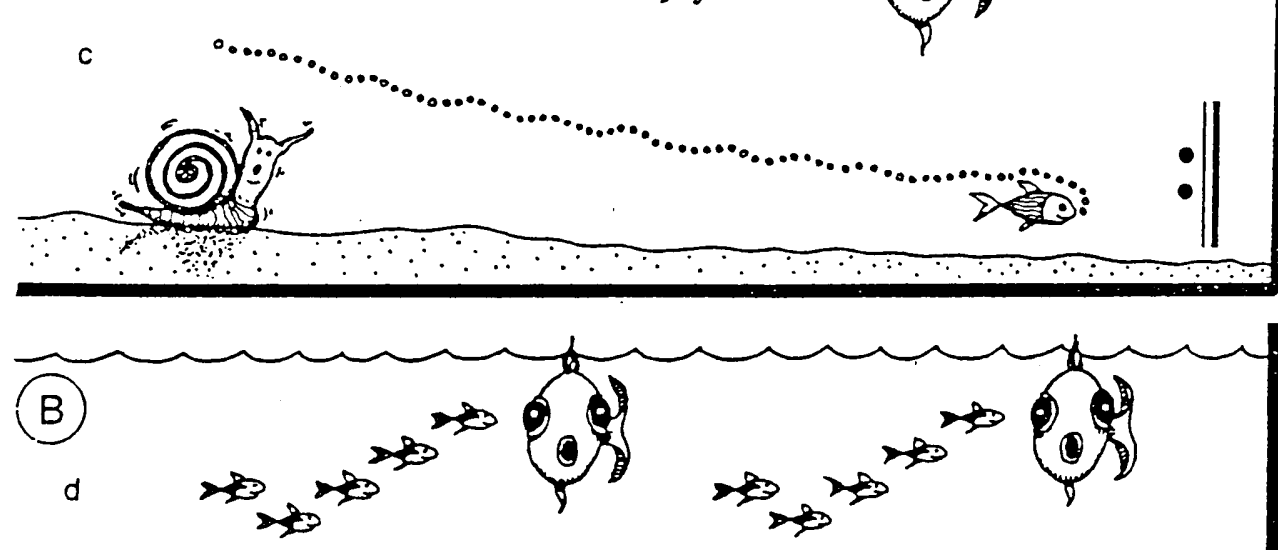

e
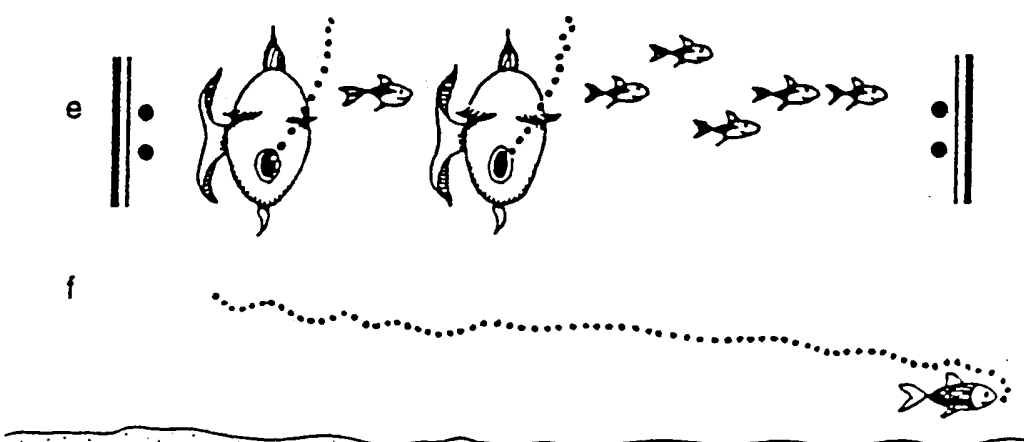

This instructional resource was provided in the MacMillan/McGraw-Hill Share the Music textbook. This textbook series is a part of the music curriculum at the school in which this study took place. 
Objectives:

1. Student will be able to visually identify $A B A$ form.

2. Student will be able to listen to and understand "March" from the Nutcracker, by Tchaikovsky.

3. Student will be able to learn basic historical facts about Tchaikovsky. (Enrichment)

Materials: Picture of Tchaikovsky, MacMillan series CD for "March", Music Listening Map (Only for group IA and IIB), ABA post-test, preference survey, Stereo, Pencils, Overhead Projector.

Procedures:

Groups IA and IIB

1. Teacher will introduce the biography of Tchaikovsky to students.

2. Teacher will explain the form ABA. Students will practice grouping symbols into ABA form with teacher on the board.

3. Teacher will introduce "March" to students. Students will listen one time to a CD recording.

4. Teacher will pass out listening maps to students. Teacher will discuss map with students: form, time signature, and repeat sign.

5. Teacher will use overhead projector to guide students through the selection with the map the first time.

6. Students will listen two more times following the map independently.

\section{Groups IB and IIA}

1. Teacher will introduce the biography of Tchaikovsky to students.

2. Teacher will explain the form ABA. Students will practice grouping symbols into ABA form with teacher on the board.

3. Teacher will introduce "March" to students. Students will listen one time to a CD recording.

4. Teacher will discuss form and time signature of the piece.

5. Students will listen 2 more times, trying to identify the A section, B section, and when the A section returns.

Assessment: Student will take ABA form Post-Test and Preference Survey. 


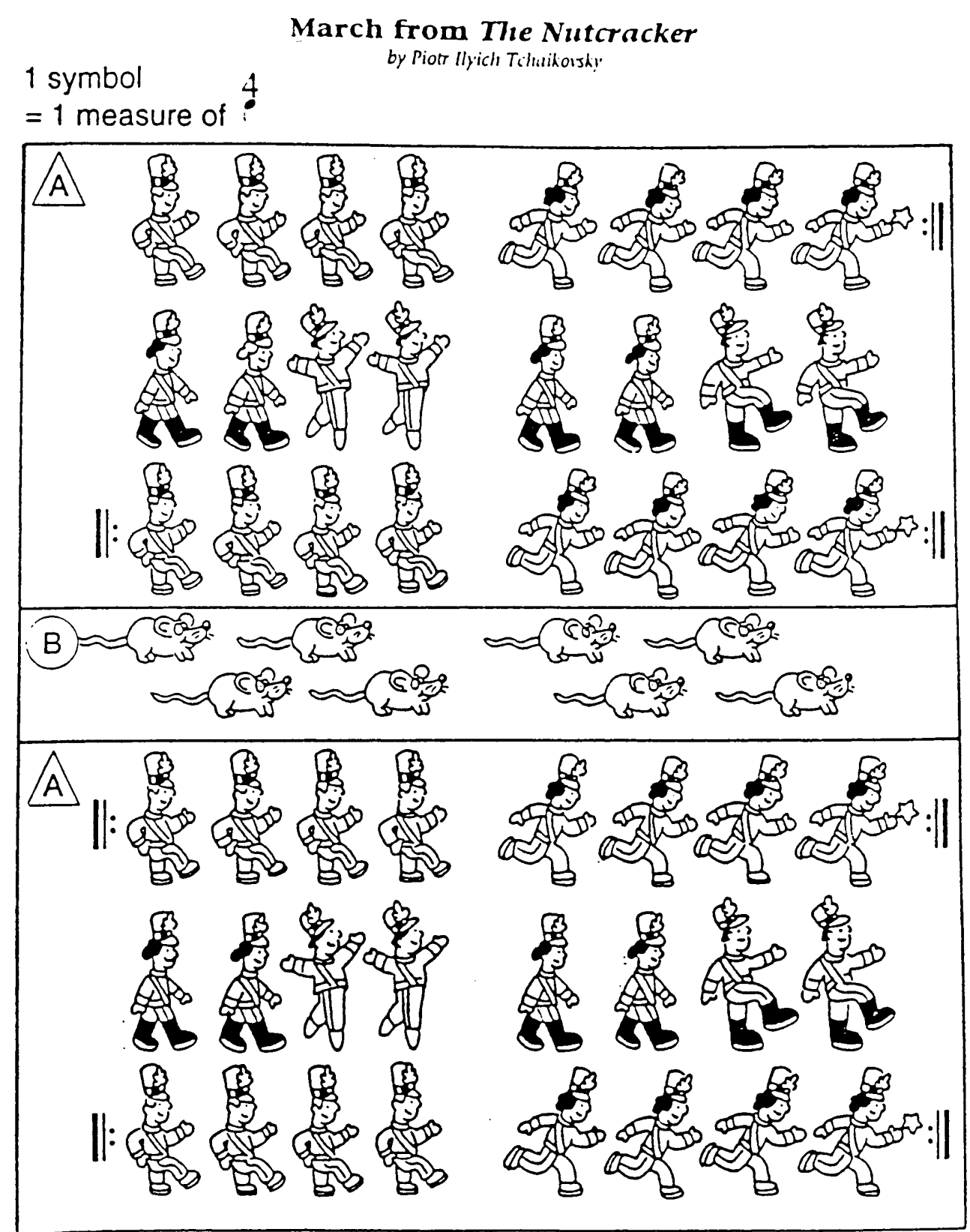

This instructional resource was provided in the MacMillan/McGraw-Hill Share the Music textbook. This textbook series is a part of the music curriculum at the school in which this study took place. 
Appendix I

Test Scores- Raw Data

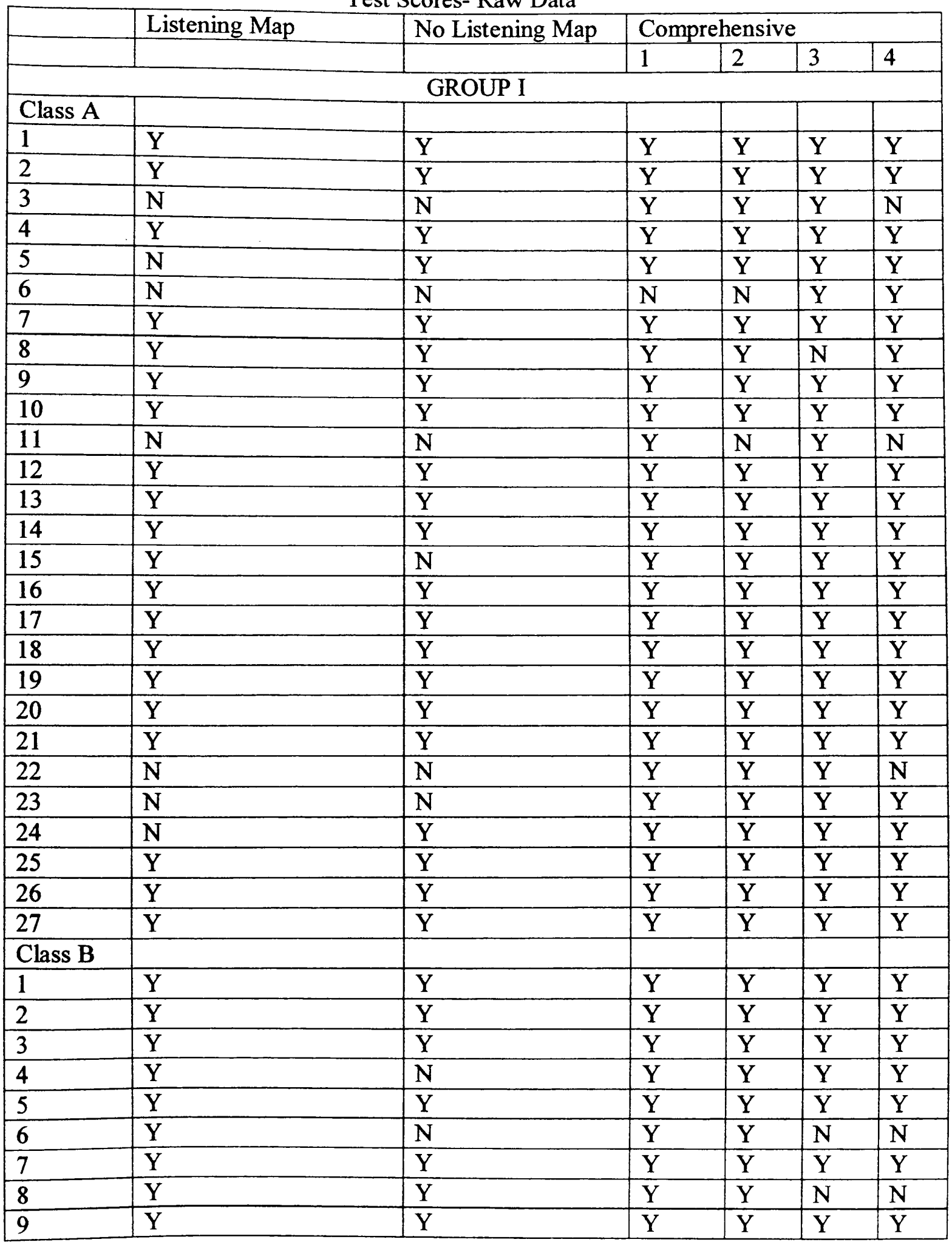




\begin{tabular}{|l|l|l|l|l|l|l|}
\hline 10 & $\mathrm{Y}$ & $\mathrm{Y}$ & $\mathrm{Y}$ & $\mathrm{Y}$ & $\mathrm{Y}$ & $\mathrm{Y}$ \\
\hline 11 & $\mathrm{Y}$ & $\mathrm{Y}$ & $\mathrm{Y}$ & $\mathrm{Y}$ & $\mathrm{Y}$ & $\mathrm{Y}$ \\
\hline 12 & $\mathrm{Y}$ & $\mathrm{Y}$ & $\mathrm{Y}$ & $\mathrm{Y}$ & $\mathrm{Y}$ & $\mathrm{Y}$ \\
\hline 13 & $\mathrm{Y}$ & $\mathrm{Y}$ & $\mathrm{Y}$ & $\mathrm{Y}$ & $\mathrm{Y}$ & $\mathrm{Y}$ \\
\hline 14 & $\mathrm{Y}$ & $\mathrm{Y}$ & $\mathrm{Y}$ & $\mathrm{Y}$ & $\mathrm{Y}$ & $\mathrm{Y}$ \\
\hline 15 & $\mathrm{Y}$ & $\mathrm{Y}$ & $\mathrm{Y}$ & $\mathrm{Y}$ & $\mathrm{Y}$ & $\mathrm{Y}$ \\
\hline 16 & $\mathrm{Y}$ & $\mathrm{Y}$ & $\mathrm{Y}$ & $\mathrm{Y}$ & $\mathrm{Y}$ & $\mathrm{Y}$ \\
\hline 17 & $\mathrm{Y}$ & $\mathrm{Y}$ & $\mathrm{Y}$ & $\mathrm{Y}$ & $\mathrm{Y}$ & $\mathrm{Y}$ \\
\hline 18 & $\mathrm{Y}$ & $\mathrm{N}$ & $\mathrm{Y}$ & $\mathrm{Y}$ & $\mathrm{Y}$ & $\mathrm{N}$ \\
\hline 19 & $\mathrm{Y}$ & $\mathrm{Y}$ & $\mathrm{Y}$ & $\mathrm{Y}$ & $\mathrm{Y}$ & $\mathrm{Y}$ \\
\hline 20 & $\mathrm{Y}$ & $\mathrm{Y}$ & $\mathrm{Y}$ & $\mathrm{Y}$ & $\mathrm{Y}$ & $\mathrm{Y}$ \\
\hline 21 & $\mathrm{Y}$ & $\mathrm{Y}$ & $\mathrm{Y}$ & $\mathrm{Y}$ & $\mathrm{N}$ & $\mathrm{N}$ \\
\hline 22 & $\mathrm{~N}$ & $\mathrm{Y}$ & $\mathrm{Y}$ & $\mathrm{Y}$ & $\mathrm{Y}$ & $\mathrm{Y}$ \\
\hline 23 & $\mathrm{Y}$ & $\mathrm{N}$ & $\mathrm{Y}$ & $\mathrm{Y}$ & $\mathrm{Y}$ & $\mathrm{Y}$ \\
\hline 24 & $\mathrm{~N}$ & $\mathrm{Y}$ & $\mathrm{Y}$ & $\mathrm{Y}$ & $\mathrm{N}$ & $\mathrm{Y}$ \\
\hline 25 & $\mathrm{Y}$ & $\mathrm{Y}$ & $\mathrm{Y}$ & $\mathrm{Y}$ & $\mathrm{Y}$ & $\mathrm{Y}$ \\
\hline 26 & $\mathrm{Y}$ & $\mathrm{Y}$ & $\mathrm{Y}$ & $\mathrm{Y}$ & $\mathrm{Y}$ & $\mathrm{Y}$ \\
\hline 27 & $\mathrm{Y}$ & $\mathrm{Y}$ & $\mathrm{Y}$ & $\mathrm{Y}$ & $\mathrm{Y}$ & $\mathrm{Y}$ \\
\hline 28 & $\mathrm{Y}$ & $\mathrm{Y}$ & - & - & - & - \\
\hline 29 & $\mathrm{~N}$ & $\mathrm{Y}$ & $\mathrm{Y}$ & $\mathrm{Y}$ & $\mathrm{Y}$ & $\mathrm{Y}$ \\
\hline 30 & $\mathrm{Y}$ & $\mathrm{Y}$ & $\mathrm{Y}$ & $\mathrm{Y}$ & $\mathrm{Y}$ & $\mathrm{Y}$ \\
\hline 31 & $\mathrm{Y}$ & $\mathrm{Y}$ & $\mathrm{Y}$ & $\mathrm{Y}$ & $\mathrm{Y}$ & $\mathrm{Y}$ \\
\hline 32 & $\mathrm{~N}$ & $\mathrm{~N}$ & $\mathrm{Y}$ & $\mathrm{Y}$ & $\mathrm{Y}$ & $\mathrm{N}$ \\
\hline
\end{tabular}




\begin{tabular}{|c|c|c|c|c|c|c|}
\hline \multicolumn{7}{|c|}{ GROUP II } \\
\hline Class C & & & & & & \\
\hline 1 & $\mathrm{Y}$ & $\mathrm{Y}$ & $\mathrm{Y}$ & $\mathrm{Y}$ & $\mathrm{Y}$ & $\mathrm{Y}$ \\
\hline 2 & $\mathrm{Y}$ & $\mathrm{Y}$ & $\mathrm{Y}$ & $\mathrm{Y}$ & $\mathrm{Y}$ & $\mathrm{Y}$ \\
\hline 3 & $\mathrm{~N}$ & $\mathrm{Y}$ & $\mathrm{Y}$ & $\mathrm{Y}$ & $\mathrm{Y}$ & $\mathrm{Y}$ \\
\hline 4 & $\bar{Y}$ & $\mathrm{Y}$ & $\mathrm{N}$ & $\mathbf{N}$ & $\bar{Y}$ & $\mathrm{Y}$ \\
\hline 5 & $\mathrm{Y}$ & $\mathrm{Y}$ & $\mathrm{Y}$ & $\mathrm{Y}$ & $\mathrm{Y}$ & $\mathrm{Y}$ \\
\hline 6 & $\mathrm{Y}$ & $\mathrm{Y}$ & $\mathrm{Y}$ & $\mathrm{Y}$ & $\mathrm{Y}$ & $\mathrm{N}$ \\
\hline 7 & $\mathrm{Y}$ & $\mathrm{Y}$ & $\mathrm{Y}$ & $\mathrm{Y}$ & $\mathrm{Y}$ & $\mathrm{Y}$ \\
\hline 8 & $\mathrm{Y}$ & $\mathrm{Y}$ & $\mathrm{Y}$ & $\mathrm{Y}$ & $\mathrm{Y}$ & $\mathrm{Y}$ \\
\hline 9 & $\mathrm{Y}$ & $\mathrm{Y}$ & $\mathrm{Y}$ & $\mathrm{Y}$ & $Y$ & $\mathrm{Y}$ \\
\hline 10 & $\mathrm{Y}$ & $\mathrm{Y}$ & $\mathrm{Y}$ & $\mathrm{Y}$ & $\mathrm{Y}$ & $\mathrm{Y}$ \\
\hline 11 & $\mathrm{Y}$ & $\mathrm{Y}$ & $\mathrm{Y}$ & $\mathrm{Y}$ & $\mathrm{Y}$ & $\mathrm{Y}$ \\
\hline 12 & $\mathrm{Y}$ & $\mathrm{Y}$ & $\mathrm{Y}$ & $\mathrm{Y}$ & $Y$ & $\mathrm{Y}$ \\
\hline 13 & $\bar{Y}$ & $\mathrm{Y}$ & $\mathrm{Y}$ & $\mathrm{Y}$ & $\mathrm{Y}$ & $\mathrm{Y}$ \\
\hline 14 & $\mathrm{Y}$ & $\mathrm{Y}$ & $Y$ & $\mathrm{Y}$ & $Y$ & $\mathrm{Y}$ \\
\hline 15 & $\mathrm{~N}$ & $\mathrm{Y}$ & $\mathrm{Y}$ & $\mathrm{Y}$ & $\mathrm{N}$ & $\mathrm{N}$ \\
\hline 16 & $\mathrm{~N}$ & $\mathrm{Y}$ & $\mathrm{Y}$ & $\mathrm{Y}$ & $Y$ & $\mathrm{Y}$ \\
\hline 17 & $\mathrm{Y}$ & $\mathrm{N}$ & $\mathrm{Y}$ & $\mathrm{Y}$ & $\mathrm{Y}$ & $\mathrm{Y}$ \\
\hline 18 & $\mathrm{Y}$ & $\mathrm{Y}$ & $\mathrm{Y}$ & $\mathrm{Y}$ & $\mathrm{Y}$ & $\mathrm{Y}$ \\
\hline 19 & $\mathrm{Y}$ & $\mathrm{Y}$ & $\mathrm{Y}$ & $\mathrm{Y}$ & $\mathrm{Y}$ & $\mathrm{Y}$ \\
\hline 20 & $\mathrm{~N}$ & $\mathrm{~N}$ & $\mathrm{Y}$ & $\mathrm{Y}$ & $\mathrm{Y}$ & $\mathrm{Y}$ \\
\hline 21 & $\mathrm{Y}$ & $\mathrm{Y}$ & $\mathrm{Y}$ & $\mathrm{Y}$ & $\mathrm{Y}$ & $\mathrm{Y}$ \\
\hline 22 & $\mathrm{Y}$ & $\mathrm{N}$ & $\mathrm{Y}$ & $\mathrm{Y}$ & $\mathrm{Y}$ & $\mathrm{Y}$ \\
\hline 23 & $\mathrm{Y}$ & $\mathbf{N}$ & $\mathrm{Y}$ & $\mathrm{Y}$ & $\mathrm{Y}$ & $\mathrm{Y}$ \\
\hline 24 & $\mathrm{Y}$ & $\bar{N}$ & $\mathrm{Y}$ & $\mathrm{Y}$ & $\mathrm{Y}$ & $\mathrm{Y}$ \\
\hline 25 & $\mathrm{Y}$ & $\mathrm{N}$ & $\mathrm{Y}$ & $\mathrm{Y}$ & $\mathrm{Y}$ & $\mathrm{N}$ \\
\hline 26 & $\mathrm{Y}$ & $\mathrm{Y}$ & $Y$ & $\mathrm{Y}$ & $\mathrm{Y}$ & $\mathrm{N}$ \\
\hline 27 & $\mathrm{Y}$ & $\mathrm{N}$ & $\mathrm{Y}$ & $\mathrm{Y}$ & $\mathrm{Y}$ & $\mathrm{N}$ \\
\hline 28 & $\mathrm{Y}$ & $\mathbf{N}$ & $\mathrm{Y}$ & $\mathrm{Y}$ & $\mathrm{N}$ & $\mathrm{Y}$ \\
\hline 29 & $\mathrm{Y}$ & $\mathrm{N}$ & $\mathrm{Y}$ & $\mathrm{Y}$ & $\mathrm{Y}$ & $\mathrm{Y}$ \\
\hline 30 & $\mathrm{Y}$ & $\mathrm{Y}$ & $\mathrm{Y}$ & $\mathrm{Y}$ & $\mathrm{Y}$ & $\mathrm{Y}$ \\
\hline \multicolumn{7}{|l|}{ Class D } \\
\hline 1 & $\mathrm{Y}$ & $\mathrm{Y}$ & $\mathrm{Y}$ & $\mathrm{Y}$ & $\mathrm{N}$ & $\mathrm{N}$ \\
\hline 2 & $\mathrm{~N}$ & $Y$ & $Y$ & $\mathrm{Y}$ & $\mathrm{N}$ & $\mathrm{Y}$ \\
\hline 3 & $\mathrm{Y}$ & $\mathrm{Y}$ & $\mathrm{Y}$ & $\mathrm{Y}$ & $\mathrm{Y}$ & $\mathrm{Y}$ \\
\hline 4 & $Y$ & $Y$ & $\mathrm{Y}$ & $\mathrm{Y}$ & $\mathrm{Y}$ & $\mathrm{Y}$ \\
\hline 5 & $Y$ & $\mathrm{Y}$ & $\mathrm{Y}$ & $\mathrm{N}$ & $\mathrm{N}$ & $\mathrm{N}$ \\
\hline 6 & $\mathrm{Y}$ & $\mathrm{Y}$ & $Y$ & $\mathrm{Y}$ & $\mathrm{Y}$ & $\mathrm{Y}$ \\
\hline 7 & $\mathrm{Y}$ & $\mathrm{Y}$ & $\mathrm{Y}$ & $\mathrm{Y}$ & $\mathrm{N}$ & $\mathrm{Y}$ \\
\hline 8 & $\mathrm{~N}$ & $\mathrm{Y}$ & $\mathrm{Y}$ & $Y$ & $\mathrm{~N}$ & $\mathrm{~N}$ \\
\hline 9 & $\mathrm{Y}$ & $\mathrm{Y}$ & $\mathrm{Y}$ & $Y$ & $\mathrm{Y}$ & $\mathrm{Y}$ \\
\hline
\end{tabular}




\begin{tabular}{|l|l|l|l|l|l|l|}
\hline 10 & $\mathrm{Y}$ & $\mathrm{Y}$ & $\mathrm{Y}$ & $\mathrm{Y}$ & $\mathrm{Y}$ & $\mathrm{Y}$ \\
\hline 11 & $\mathrm{Y}$ & $\mathrm{Y}$ & $\mathrm{Y}$ & $\mathrm{Y}$ & $\mathrm{Y}$ & $\mathrm{Y}$ \\
\hline 12 & $\mathrm{Y}$ & $\mathrm{Y}$ & $\mathrm{Y}$ & $\mathrm{Y}$ & $\mathrm{Y}$ & $\mathrm{Y}$ \\
\hline 13 & $\mathrm{Y}$ & $\mathrm{Y}$ & $\mathrm{Y}$ & $\mathrm{Y}$ & $\mathrm{Y}$ & $\mathrm{Y}$ \\
\hline 14 & $\mathrm{Y}$ & $\mathrm{Y}$ & - & - & - & - \\
\hline 15 & $\mathrm{Y}$ & $\mathrm{Y}$ & $\mathrm{Y}$ & $\mathrm{Y}$ & $\mathrm{Y}$ & $\mathrm{Y}$ \\
\hline 16 & $\mathrm{Y}$ & $\mathrm{Y}$ & $\mathrm{Y}$ & $\mathrm{Y}$ & $\mathrm{Y}$ & $\mathrm{Y}$ \\
\hline 17 & $\mathrm{Y}$ & $\mathrm{Y}$ & $\mathrm{Y}$ & $\mathrm{Y}$ & $\mathrm{Y}$ & $\mathrm{Y}$ \\
\hline 18 & $\mathrm{Y}$ & $\mathrm{Y}$ & $\mathrm{Y}$ & $\mathrm{Y}$ & $\mathrm{Y}$ & $\mathrm{Y}$ \\
\hline 19 & $\mathrm{Y}$ & $\mathrm{Y}$ & $\mathrm{Y}$ & $\mathrm{Y}$ & $\mathrm{Y}$ & $\mathrm{Y}$ \\
\hline 20 & $\mathrm{Y}$ & $\mathrm{Y}$ & $\mathrm{Y}$ & $\mathrm{Y}$ & $\mathrm{Y}$ & $\mathrm{Y}$ \\
\hline 21 & $\mathrm{Y}$ & $\mathrm{Y}$ & $\mathrm{Y}$ & $\mathrm{Y}$ & $\mathrm{Y}$ & $\mathrm{Y}$ \\
\hline 22 & $\mathrm{Y}$ & $\mathrm{Y}$ & $\mathrm{Y}$ & $\mathrm{Y}$ & $\mathrm{Y}$ & $\mathrm{Y}$ \\
\hline 23 & $\mathrm{Y}$ & $\mathrm{Y}$ & $\mathrm{Y}$ & $\mathrm{Y}$ & $\mathrm{Y}$ & $\mathrm{Y}$ \\
\hline 24 & $\mathrm{Y}$ & $\mathrm{Y}$ & $\mathrm{Y}$ & $\mathrm{Y}$ & $\mathrm{Y}$ & $\mathrm{Y}$ \\
\hline 25 & $\mathrm{Y}$ & $\mathrm{Y}$ & $\mathrm{Y}$ & $\mathrm{Y}$ & $\mathrm{Y}$ & $\mathrm{Y}$ \\
\hline 26 & $\mathrm{Y}$ & $\mathrm{Y}$ & $\mathrm{Y}$ & $\mathrm{Y}$ & $\mathrm{Y}$ & $\mathrm{Y}$ \\
\hline 27 & $\mathrm{Y}$ & $\mathrm{Y}$ & $\mathrm{Y}$ & $\mathrm{Y}$ & $\mathrm{Y}$ & $\mathrm{Y}$ \\
\hline 28 & $\mathrm{Y}$ & $\mathrm{Y}$ & $\mathrm{Y}$ & $\mathrm{Y}$ & $\mathrm{Y}$ & $\mathrm{Y}$ \\
\hline 29 & $\mathrm{Y}$ & $\mathrm{Y}$ & $\mathrm{Y}$ & $\mathrm{Y}$ & $\mathrm{Y}$ & $\mathrm{N}$ \\
\hline
\end{tabular}

Class A- LM $1^{\text {st }}$

Class B- LM $1^{\text {st }}$

Class C- NLM $1^{\text {st }}$

Class D- NLM 1st 
Appendix J

Raw Data Affective Survey

\begin{tabular}{|c|c|c|c|c|c|c|c|c|c|c|c|c|c|c|c|c|c|c|c|c|c|c|c|c|c|c|c|c|c|}
\hline & & $\# 1$ & & & $\# 2$ & & & $\# 3$ & & & $\# 4$ & & & $\# 5$ & & & $\# 6$ & & & $\# 7$ & & & $\# 8$ & & \#9 & & & & \\
\hline $\begin{array}{c}\text { Class } \\
\text { A }\end{array}$ & (2) & $\oplus$ & (8) & (4) & $\oplus$ & (8) & (1) & (ब) & ब(ब) & (i) & $\oplus$ & (ब) & (2) & (-) & (ब) & (ㄹ) & (;) & (ब) & (3) & & (1) & (2) & (ब) & (ब) & (9) & $\otimes$ & (ब) & $9 / 8$ & \\
\hline 1 & $\mathbf{x}$ & & & $\mathrm{X}$ & & & $\mathbf{X}$ & & & & $\bar{X}$ & & & $\mathbf{X}$ & & & $\mathbf{X}$ & & $\bar{X}$ & & & $\mathbf{x}$ & & & & $\overline{\mathbf{X}}$ & & & \\
\hline 2 & $\mathbf{X}$ & & & $\bar{X}$ & & & $\mathbf{x}$ & & & $\mathbf{X}$ & & & $\overline{\mathbf{X}}$ & & & $\mathrm{X}$ & & & $\bar{X}$ & . & $T$ & & $\mathbf{X}$ & & $\mathrm{X}$ & & $\mathrm{X}$ & & \\
\hline 3 & $\bar{x}$ & & 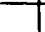 & & & $\overline{\mathbf{X}}$ & & $\overline{\mathbf{X}}$ & & $\bar{X}$ & & & & $\overline{\mathbf{X}}$ & & & & $\mathbf{X}$ & $\overline{\mathbf{X}}$ & & & & $\overline{\mathbf{X}}$ & & & $\overline{\mathbf{X}}$ & $\overline{\mathbf{X}}$ & & \\
\hline 4 & $\mathbf{X}$ & & & $\overline{\mathbf{X}}$ & & & $\mathrm{X}$ & & & $\bar{X}$ & & & $\bar{X}$ & & & & $\mathbf{x}$ & & $\bar{X}$ & & & & $\bar{X}$ & & $\mathbf{x}$ & & & & \\
\hline 5 & $\mathbf{X}$ & & & $\mathrm{X}$ & - & & $\overline{\mathbf{X}}$ & & & $\bar{x}$ & & & $\overline{\mathbf{X}}$ & & & $\mathbf{X}$ & & & $\overline{\mathbf{X}}$ & & & & $\bar{X}$ & & $x$ & & $\mathbf{X}$ & & \\
\hline 6 & $X$ & & & & & & $\bar{X}$ & & & $\mathbf{x}$ & & & & & & $\mathbf{X}$ & - & & $\bar{X}$ & & & & & & & & & & \\
\hline 7 & $\mathbf{X}$ & & & $\mathrm{X}$ & & & $\bar{x}$ & & & & $\bar{X}$ & & $\bar{x}$ & & & $\bar{X}$ & & & & $\overline{\mathbf{X}}$ & & & 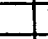 & $\bar{x}$ & X & & $\overline{\mathrm{X}}$ & & \\
\hline 8 & & & & & & & & & & $\bar{X}$ & & & $\overline{\mathbf{X}}$ & & & $\bar{X}$ & & & & & & & & & 7 & & $\mathbf{X}$ & & \\
\hline 9 & $\mathbf{X}$ & & & & $\overline{\mathbf{X}}$ & & $\bar{X}$ & & & $\bar{X}$ & 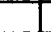 & & & $\bar{X}$ & & $\overline{\mathbf{X}}$ & & & $\overline{\mathbf{X}}$ & . & & $\overline{\mathbf{X}}$ & & & X & & $\overline{\mathbf{X}}$ & & \\
\hline 10 & $\mathbf{X}$ & & & & $\mathbf{X}$ & & $\mathrm{X}$ & & & $\mathbf{X}$ & & & $\overline{\mathbf{x}}$ & & & & $\mathbf{X}$ & & $\bar{X}$ & & & & $\bar{X}$ & & X & & & & \\
\hline 11 & $\mathbf{X}$ & & & $\overline{\mathbf{X}}$ & & & & $\mathbf{X}$ & & $\mathbf{X}$ & & & $\overline{\mathbf{X}}$ & & & $\overline{\mathbf{X}}$ & . & & & $\mathbf{X}$ & & & & $\mathbf{X}$ & 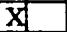 & & $\mathbf{x}$ & & \\
\hline 12 & $\mathbf{X}$ & & & $\bar{X}$ & 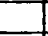 & & - & $\mathbf{x}$ & & $\mathbf{X}$ & & & & $x$ & & $\mathbf{X}$ & & & $\overline{\mathbf{X}}$ & & & $\mathbf{X}$ & & & $\overline{\mathbf{x}}$ & & $\mathbf{x}$ & & \\
\hline 13 & $\mathrm{X}$ & & & $\mathrm{X}$ & & & & $\mathrm{X}$ & & $\mathrm{x}$ & 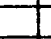 & & & 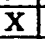 & & & $\mathbf{X}$ & & & $\overline{\mathbf{X}}$ & & $\bar{x}$ & & & $\mathrm{X}$ & & $\mathrm{X}$ & & \\
\hline 14 & & & $\mathbf{X}$ & $\mathbf{X}$ & & & $\mathbf{X}$ & & & $\underline{\mathbf{X}}$ & & & $\mathbf{X}$ & & & $\mathbf{X}$ & & & $\mathbf{X}$ & & & $\mathbf{X}$ & & & $\mathbf{X}$ & & $\mathbf{X}$ & & \\
\hline 15 & & $\mathbf{X}$ & & & - & $\mathbf{X}$ & $\mathrm{X}$ & & & $\bar{X}$ & & & $\mathbf{X}$ & 7 & & $\bar{X}$ & & & $\bar{X}$ & & & & & $\underline{\mathbf{X}}$ & X & & $\mathbf{x}$ & & \\
\hline 16 & $\bar{X}$ & & & $\bar{X}$ & & & $\bar{x}$ & & & $\bar{X}$ & & & $\bar{X}$ & & & $\bar{X}$ & & & $\bar{X}$ & & & $\mathbf{X}$ & & & $x$ & & $\mathbf{x}$ & & \\
\hline 17 & & $\overline{\mathbf{X}}$ & & $\overline{\mathrm{x}}$ & & & $\bar{X}$ & & & & & $\mathbf{X}$ & & $\overline{\mathbf{X}}$ & & $\overline{\mathbf{X}}$ & & & 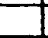 & & $\mathbf{X}$ & & & $\mathrm{X}$ & $x$ & & 7 & $\overline{\mathbf{X}}$ & \\
\hline 18 & & $\mathbf{X}$ & & & $\bar{x}$ & & & & $\mathbf{X}$ & & & $\bar{X}$ & & $\bar{X}$ & & & $\mathbf{X}$ & & & & & 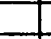 & & $\bar{X}$ & $x$ & & \begin{tabular}{|l|l}
$\mathbf{X}$ & \\
\end{tabular} & & \\
\hline 19 & $\bar{X}$ & & & $\mathbf{X}$ & & & $\mathbf{X}$ & & & $\mathbf{X}$ & $\ldots$ & & & $\underline{\mathbf{X}}$ & & . & & $\mathbf{X}$ & & & $\bar{X}$ & & $\mathbf{X}$ & & $x$ & & $\mathbf{X}$ & & \\
\hline 20 & & $\bar{X}$ & & $\bar{X}$ & & & $\mathbf{X}$ & & & $\mathbf{X}$ & & & $\underline{X}$ & & & & & $\mathbf{X}$ & $\mathbf{X}$ & & & $\mathrm{X}$ & & & $\mathbf{x}$ & & $\bar{x}$ & & \\
\hline 21 & $\mathrm{X}$ & & & $\bar{X}$ & & & & $\mathbf{x}$ & & $x$ & 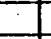 & & & & $\mathbf{X}$ & - & $\overline{\mathbf{X}}$ & & & & $\overline{\mathbf{X}}$ & $\bar{X}$ & & & $x$ & & & $\underline{\mathbf{X}}$ & \\
\hline 22 & $\bar{x}$ & & & & $\bar{X}$ & & $\mathbf{X}$ & & & & & $\mathbf{X}$ & $\bar{X}$ & & & & $\overline{\mathbf{X}}$ & & $\bar{X}$ & & & $\mathbf{X}$ & & & $7 \bar{x}$ & & & & X \\
\hline 23 & $\mathbf{X}$ & & & $\overline{\mathbf{X}}$ & & & $\overline{\mathbf{X}}$ & & & $\mathbf{X}$ & & & $\mathbf{X}$ & & & $\mathrm{X}$ & & & $\mathbf{X}$ & & & $\mathbf{X}$ & & & $\mathrm{X}$ & & $\mathbf{X}$ & & \\
\hline 24 & $\mathrm{X}$ & & & & & & & & & & & & $\mathbf{X}$ & & & $\bar{X}$ & & & $\mathrm{X}$ & & & $\mathbf{X}$ & & & & & & & \\
\hline 25 & & $\mathbf{X}$ & & $\mathrm{X}$ & & & & & $\bar{X}$ & & $\mathrm{X}$ & & $\bar{X}$ & & & $\mathbf{x}$ & & & & $\bar{X}$ & & & & $\mathbf{X}$ & X & & $\overline{\mathbf{X}} \mid$ & & \\
\hline 26 & $\mathbf{X}$ & & & $\bar{X}$ & & & & $\mathbf{X}$ & & $\mathbf{X}$ & & & $\mathbf{X}$ & & & $\mathrm{X}$ & & & & $\mathbf{X}$ & & & $\bar{X}$ & & $\bar{x}$ & & \begin{tabular}{|l|} 
\\
\end{tabular} & & \\
\hline 27 & $\bar{x}$ & & & $\mathbf{X}$ & & & $\mathrm{X}$ & & & $\bar{X}$ & & & $\mathbf{X}$ & & & $\mathbf{X}$ & & & $\overline{\mathbf{X}}$ & & & $\mathbf{X}$ & & & $x$ & & \begin{tabular}{|l|}
$\mathbf{X}$ \\
\end{tabular} & & \\
\hline
\end{tabular}




\begin{tabular}{|c|c|c|c|c|c|c|c|c|c|c|c|c|c|c|c|c|c|c|c|c|c|c|c|c|c|c|c|c|}
\hline & & & & & 2 & & $\# 3$ & & & $\# 4$ & & & \#5 & & & $\$ 6$ & & & $\# 7$ & & & $\# 8$ & & \#S & & & 110 & \\
\hline $\begin{array}{c}\text { Class } \\
\text { B }\end{array}$ & (9) & & 6 & (7) & 98 & (1) & $\oplus$ & (2) & (1) & (ब) & (8) & ()ㅏㅇ & $\oplus$ & (2) & 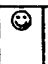 & & & (i) & & (8) & (-) & & (ब) & & 98 & (ब) & ब्र & (8) \\
\hline 1 & $\mathrm{X}$ & & $\bar{z}$ & $\bar{x}$ & & $\bar{x}$ & & & $\bar{X}$ & & & $\bar{x}$ & & & $\bar{x}$ & & & $\bar{x}$ & & & $\overline{\mathbf{X}}$ & & & 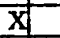 & & $\mathrm{X}$ & & \\
\hline 2 & $\mathbf{x}$ & & $\overline{2}$ & $\bar{x}$ & & $\bar{x}$ & & & $\bar{x}$ & & & $\overline{\mathbf{X}}$ & & & $\bar{x}$ & & & $X$ & & & $\mathbf{x}$ & & & X & & $\mathrm{X}$ & & \\
\hline 3 & $\mathrm{x}$ & & $\bar{x}$ & $\underline{x}$ & & $x$ & & & & $\bar{X}$ & & & & $\overline{\mathbf{X}}$ & & & $\mathbf{X}$ & $\mathbf{X}$ & & & & & $\mathbf{X}$ & X & & & $\mathbf{X}$ & \\
\hline 4 & $\mathbf{x}$ & & $\bar{x}$ & $\underline{\underline{X}}$ & & $\bar{X}$ & & & $X$ & & & $\mathbf{X}$ & & & $X$ & & & $\bar{X}$ & & & $\mathbf{X}$ & & & $\mathrm{X}$ & & $\mathbf{X}$ & & \\
\hline 5 & $\mathrm{x}$ & & $\bar{x}$ & $\bar{x}$ & & $x$ & & & $\mathbf{X}$ & & & $\mathbf{X}$ & & & $\mathbf{X}$ & & & $\mathbf{X}$ & & & $\mathbf{x}$ & & & $\mathrm{X}$ & & $\mathbf{X}$ & & \\
\hline 6 & $\mid \bar{x}$ & & $\overline{3}$ & $\bar{x}$ & & $\mathrm{X}$ & & & $\bar{X}$ & & & $\bar{X}$ & & & $\bar{x}$ & & & $\bar{X}$ & & & $\overline{\mathrm{X}}$ & & & $\mathrm{X}$ & & $\mathbf{x}$ & & \\
\hline 7 & $\mathbf{X}$ & & $\overline{2}$ & $\bar{X}$ & & $\bar{X}$ & & & $\bar{X}$ & & & $\bar{X}$ & & & $\overline{\mathbf{x}}$ & & 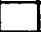 & $\bar{X}$ & & & $\bar{X}$ & & & $x$ & & $\mathbf{x}$ & & \\
\hline 8 & $\mathbf{x}$ & & $\bar{X}$ & $\mathbf{X}$ & & $\bar{x}$ & & & $\mathbf{X}$ & & & $\mathrm{X}$ & & & $\mathbf{X}$ & & & $\bar{X}$ & & & $\mathbf{X}$ & & & $\mathrm{X}$ & & $\mathbf{x}$ & & \\
\hline 9 & $\mathbf{X}$ & & 2 & $x$ & & $\mathrm{X}$ & & & $\mathbf{X}$ & & & $\mathbf{X}$ & & & $\mathbf{X}$ & & & $\bar{X}$ & & & $\bar{X}$ & & & $1 x$ & & & $\bar{x}$ & \\
\hline 10 & & & & & $\mathbf{X}$ & $\mathbf{X}$ & & & & $\mathbf{x}$ & & $\mathbf{x}$ & & & $\mathbf{x}$ & & & $\bar{x}$ & & & $\bar{X}$ & & & $\sqrt{x}$ & & & $\mathrm{X}$ & \\
\hline 11 & $x$ & & $\frac{7}{7}$ & $X$ & & $x$ & & & $\mathrm{X}$ & & & & $\mathbf{X}$ & & & & $\mathbf{x}$ & & & $\mathbf{X}$ & $x$ & & & $x$ & & $\mathbf{X}$ & & \\
\hline 12 & $\mathrm{X}$ & & $\overline{2}$ & $\underline{x}$ & & $\bar{x}$ & & & - & $\mathbf{X}$ & & $\mathbf{X}$ & & & $\mathbf{X}$ & & & 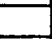 & $\mathrm{X}$ & & - & $\mathbf{X}$ & & X & & \begin{tabular}{|l|}
$\mathrm{X}$ \\
\end{tabular} & & \\
\hline 13 & & & & & & & & & & & & & & & & & & & & & & & & & & & & \\
\hline 14 & $\mathbf{x}$ & & $\bar{I}$ & $\mathbf{X}$ & & & $\mathbf{X}$ & & $\mathbf{x}$ & & & $\mathbf{X}$ & & & $\mathbf{X}$ & & & & $\mathrm{X}$ & & $\mathbf{X}$ & & & 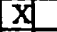 & & $\mathbf{X}$ & & \\
\hline 15 & $\mathbf{X}$ & & & & $\underline{X}$ & $\mathrm{X}$ & & & & & $\mathbf{X}$ & $\mathrm{X}$ & & & & & $\underline{\mathbf{X}}$ & $X$ & & & & & $\mathrm{X}$ & $x$ & & \begin{tabular}{|l|}
$\mathbf{X}$ \\
\end{tabular} & & \\
\hline 16 & $\mathrm{x}$ & & 2 & $X$ & & \begin{tabular}{|l|}
$x$ \\
\end{tabular} & & & $\mathbf{X}$ & & 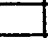 & $x$ & & & $\mathrm{X}$ & & -1 & $x$ & & & $\mathbf{X}$ & & & $x$ & & \begin{tabular}{|l|}
$\mathbf{X}$ \\
\end{tabular} & & \\
\hline 17 & $\mathbf{X}$ & & 2 & $\bar{x}$ & & $\mathbf{X}$ & & & $\mathbf{X}$ & & & $x$ & & & $\mathrm{X}$ & & & $\bar{x}$ & & & $\bar{x}$ & & & X & & $\mathbf{x}$ & & \\
\hline 18 & $\mathrm{X}$ & & $\overline{2}$ & $\bar{X}$ & & $\bar{x}$ & & & $\bar{x}$ & & & $\bar{X}$ & & & $x$ & & & $\bar{x}$ & & & $x$ & & & X & & $\bar{X}$ & & \\
\hline 19 & $\mathbf{X}$ & & 2 & 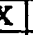 & & $x$ & & & $\mathbf{x}$ & & & $\mathbf{X}$ & & & $\bar{x}$ & & & $X$ & & & $\mathbf{X}$ & & & $\mathrm{X}$ & & $\mathbf{X}$ & & \\
\hline 20 & $\mathbf{x}$ & & 2 & $\bar{X}$ & & $\bar{x}$ & & & $\bar{X}$ & & & $\overline{\mathbf{X}}$ & & & $\mathbf{X}$ & & & $\bar{X}$ & & & $\mathbf{X}$ & & & $\mathrm{X}$ & & $\mathbf{X}$ & & \\
\hline 21 & $\mathrm{X}$ & & & $x$ & & $\mathbf{x}$ & & & $\mathrm{X}$ & & & $\mathrm{X}$ & & & & & $\mathrm{X}$ & $\mathbf{X}$ & & & $\mathbf{X}$ & & & $x$ & & $\mathrm{X}$ & & \\
\hline 22 & & & $\overline{2}$ & $\overline{\mathbf{X}}$ & & $\bar{x}$ & & & $\mathbf{x}$ & & & $\bar{X}$ & & & $\mathbf{X}$ & & & $\bar{x}$ & & & $\mathbf{X}$ & & & $\mathrm{X}$ & & & & \\
\hline 23 & $\mathbf{x}$ & & 2 & $\bar{x}$ & & $x$ & & & $\mathbf{x}$ & & & $\mathbf{X}$ & & & $\mathrm{X}$ & & & $x$ & & & $\mathbf{X}$ & & & $x$ & & $\mathrm{X}$ & & \\
\hline 24 & $\mathbf{x}$ & & $\overline{2}$ & $\bar{x}$ & & $\mathrm{X}$ & & & $x$ & & & $x$ & & & & $\mathbf{X}$ & & $\mathbf{X}$ & & & & $\mathbf{X}$ & & 52 & X] & & & $\mathbf{x}$ \\
\hline 25 & $\mathrm{X}$ & & $\overline{2}$ & $\underline{X}$ & & $x$ & & & $\mathbf{X}$ & & & & $\mathbf{X}$ & & & $\mathrm{X}$ & & & $\mathrm{X}$ & & $\mathbf{X}$ & & & 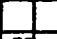 & $\mathrm{X}$ & & & $\underline{X}$ \\
\hline 26 & & & & & & & & & & & & & 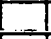 & & $x$ & & & $\mathbf{x}$ & & & $\mathbf{X}$ & & & $x$ & & $\bar{x}$ & & \\
\hline 27 & & & 2 & $\bar{X}$ & & $\bar{x}$ & & & $\bar{x}$ & & & $\mathbf{X}$ & & & $\mathrm{X}$ & & & & & & $\mathbf{X}$ & & & X & & & & \\
\hline 28 & $\mathrm{x}$ & & $\frac{2}{2}$ & $x$ & & $\mathbf{X}$ & & & $\mathbf{X}$ & & & $\mathbf{X}$ & & & $\mathbf{X}$ & & & $\mathrm{X}$ & & & $\mathbf{x}$ & & & X & & $\bar{x}$ & & \\
\hline 29 & $\mathbf{X}$ & & 5 & $\overline{\mathbf{x}}$ & & $\mathbf{x}$ & & & $\bar{x}$ & & & $\bar{x}$ & & & $\bar{X}$ & & & $\mathbf{X}$ & & & $\overline{\mathbf{X}}$ & & & X] & & $\bar{x}$ & & \\
\hline 30 & $\mathbf{x}$ & & & $\bar{x}$ & & $\mathbf{x}$ & & & $\bar{x}$ & & & $\mathbf{X}$ & & & $\mathbf{X}$ & & & $\mathbf{X}$ & & & $\mathbf{X}$ & & & x & & $X$ & & \\
\hline 31 & $\mathrm{X}$ & & 2 & $\bar{X}$ & & $\mathbf{X}$ & & & $\mathbf{x}$ & & & $\mathrm{X}$ & & & $\mathbf{x}$ & & & $\mathbf{x}$ & & & $\bar{x}$ & & & $\mathrm{x}$ & & $\mathbf{x}$ & & \\
\hline 32 & & & & $\bar{x}$ & & & $\bar{x}$ & & $\mathrm{X}$ & & & & $\mathbf{X}$ & & & & $\mathbf{X}$ & $\mathbf{X}$ & & & $\mathbf{X}$ & & & X & & 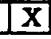 & & \\
\hline
\end{tabular}




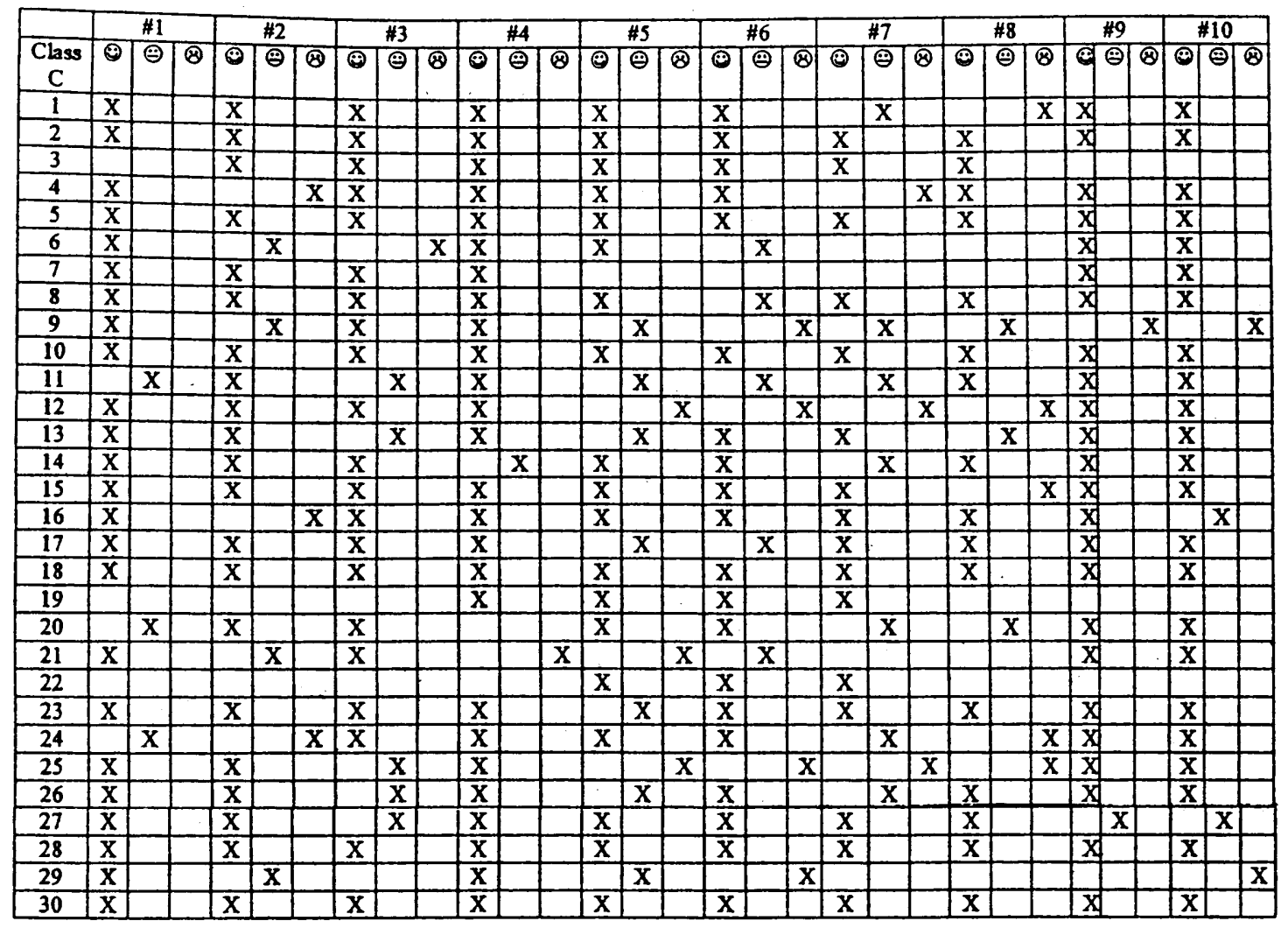




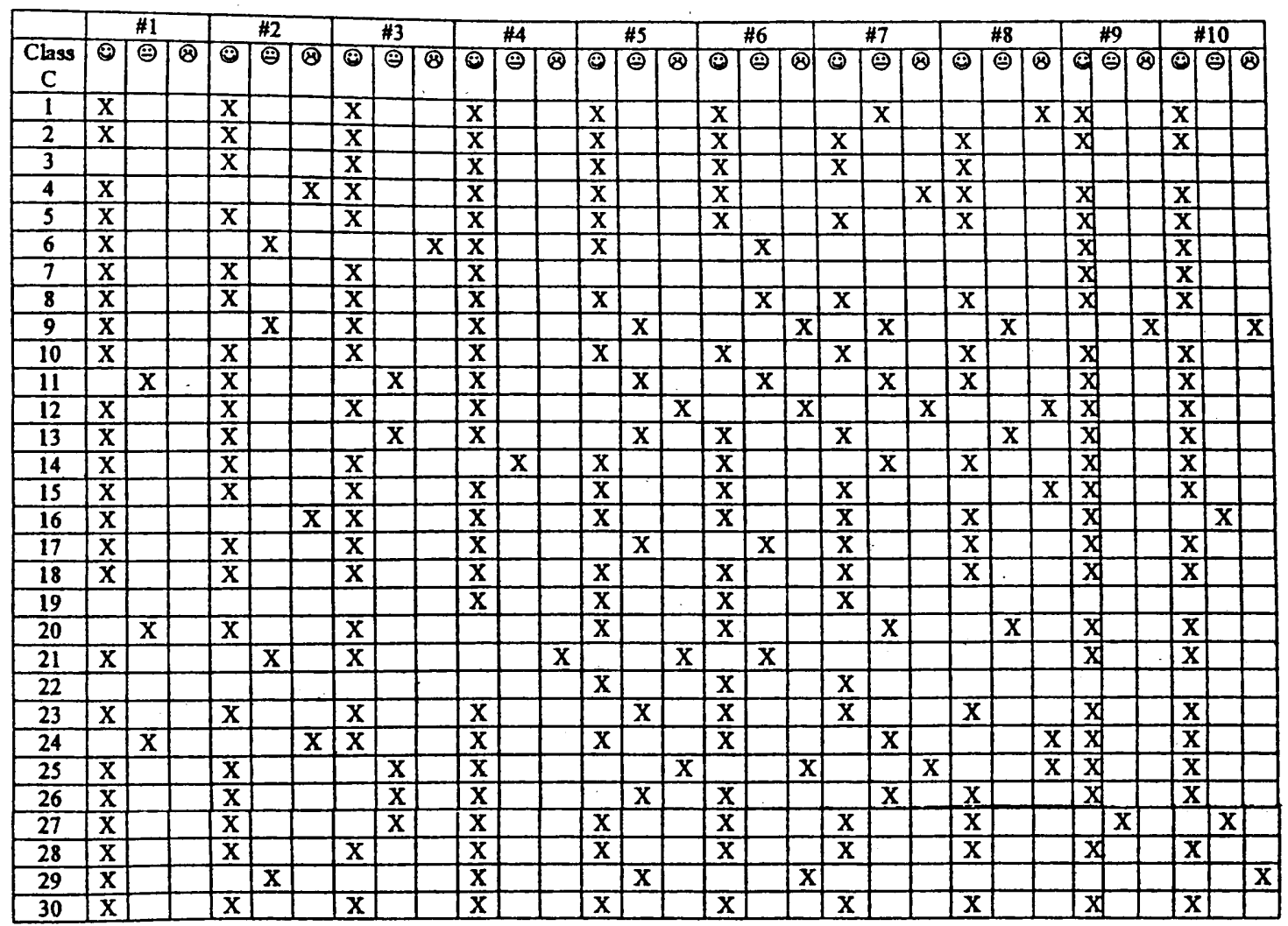




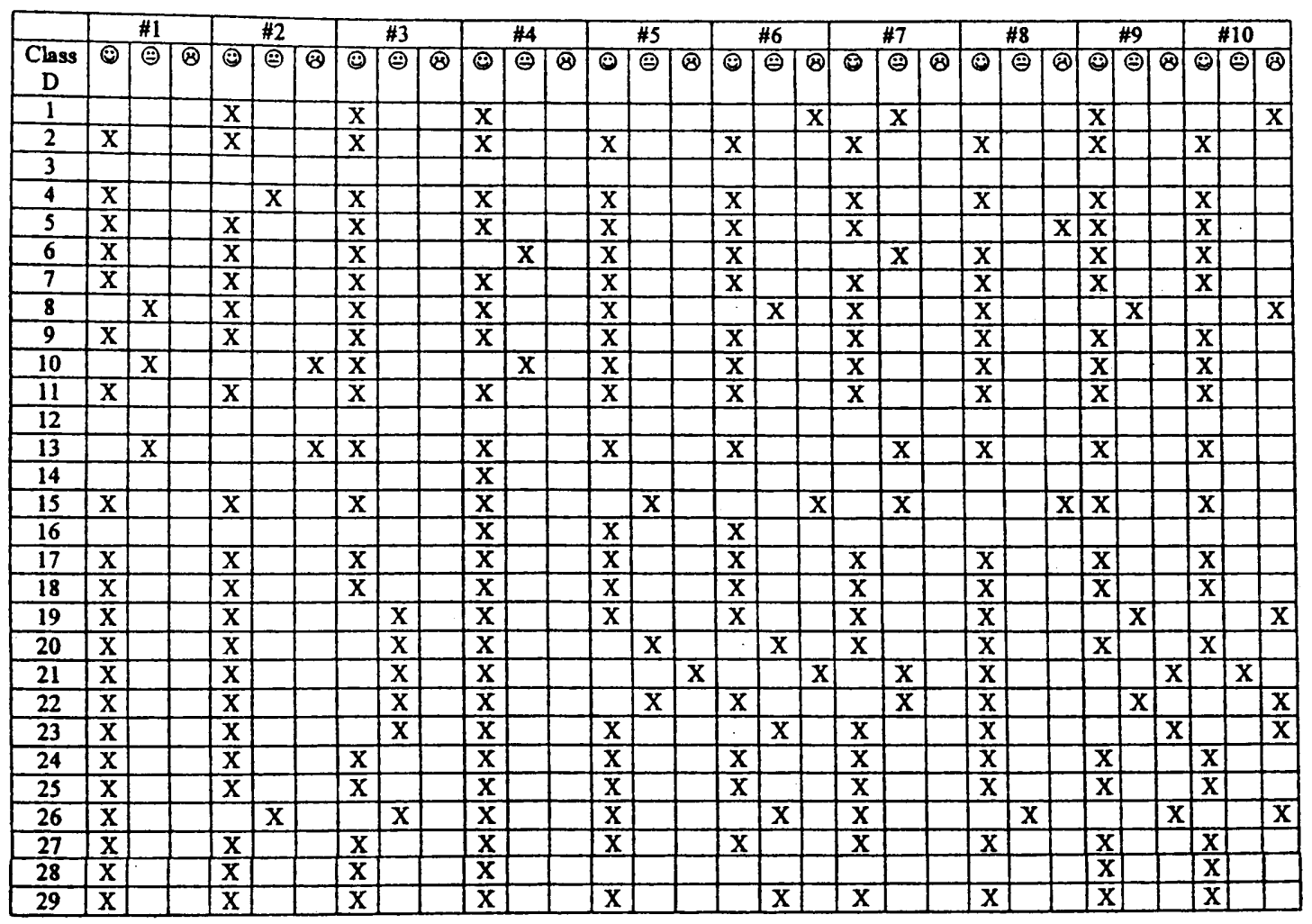

